\title{
Morphological traits predict host-tree specialization in wood-inhabiting fungal communities
}

\section{Purhonen, Jenna}

2020-08

Purhonen , J , Ovaskainen, O , Halme , P , Komonen , A, Huhtinen , S , Kotiranta , H , Laessoe , T \& Abrego , N 2020 , ' Morphological traits predict host-tree specialization in wood-inhabiting fungal communities ' , Fungal Ecology , vol. 46 , 100863 . https://doi.org/10.1016/j.funeco.2019.08.0

http://hdl.handle.net/10138/326193

https://doi.org/10.1016/j.funeco.2019.08.007

CC BY-NC-ND

acceptedVersion

Downloaded from Helda, University of Helsinki institutional repository.

This is an electronic reprint of the original article.

This reprint may differ from the original in pagination and typographic detail.

Please cite the original version. 
Morphological traits predict host-tree specialization in wood-inhabiting fungal communities

Purhonen Jenna ${ }^{1,2^{*}}$, Ovaskainen Otso ${ }^{3,4}$, Halme Panu ${ }^{1,2}$, Komonen Atte ${ }^{1,2}$, Huhtinen Seppo ${ }^{5}$, Kotiranta Heikki ${ }^{6}$, Læssøe Thomas ${ }^{7}, \&$ Abrego Nerea ${ }^{8}$

${ }^{1}$ Department of Biological and Environmental Science, University of Jyväskylä, P.O. Box 35, FI-40014 University of Jyväskylä, Finland

${ }^{2}$ School of Resource Wisdom, University of Jyväskylä, P.O. Box 35, FI-40014 University of Jyväskylä, Finland

${ }^{3}$ Organismal and Evolutionary Biology Research Programme, PO Box, 65, FI-00014 University of Helsinki, Finland

${ }^{4}$ Centre for Biodiversity Dynamics, Norwegian University of Science and Technology, N-7491 Trondheim, Norway

${ }^{5}$ Herbarium, Biodiversity Unit, University of Turku, FI-20014 Turku, Finland.

${ }^{6}$ Biodiversity Unit, Finnish Environment Institute, P.O. Box 140, FI-00251, Helsinki, Finland

${ }^{7}$ Department of Biology/Natural History Museum of Denmark, University of Copenhagen, Universitetsparken 15, Copenhagen 2100 Ø, Denmark

${ }^{8}$ Department of Agricultural Sciences, PO Box 27, FI-00014 University of Helsinki, Finland

*Corresponding author, jenna.purhonen@jyu.fi, +358442599515 


\begin{abstract}
Tree species is one of the most important determinants of wood-inhabiting fungal community composition, yet its relationship with fungal reproductive and dispersal traits remains poorly understood. We studied fungal communities (total of 657 species) inhabiting broadleaved and coniferous dead wood (total of 192 logs) in 12 semi-natural boreal forests. We utilized a traitbased hierarchical joint species distribution model to examine how the relationship between dead wood quality and species occurrence correlates with reproductive and dispersal morphological traits. Broadleaved trees had higher species richness than conifers, due to discomycetoids and pyrenomycetoids specializing in them. Resupinate and pileate species were generally specialized in coniferous dead wood. Fungi inhabiting broadleaved trees had larger and more elongated spores than fungi in conifers. Spore size was larger and spore shape more spherical in species occupying large dead wood units. These results indicate the selective effect of dead wood quality, visible not only in species diversity, but also in reproductive and dispersal traits.
\end{abstract}

Index descriptors: broadleaved, coniferous, dead wood, functional trait, fruitbody, morphology, specialization, spore, tree species 


\section{INTRODUCTION}

Functional traits in fungi can be defined as any morphological, physiological or phenological feature affecting the fitness of an individual fungus (Dawson et al., 2018). Knowledge of the relationship between species traits and species responses to environmental conditions provides understanding of the mechanisms influencing community assembly in different environments (McGill et al., 2006; Weiher et al., 2011). Although trait-based assessments of communitylevel responses in the fungal kingdom have lagged behind that of animal and plant communities, currently fungal ecological research is undergoing a proliferation of empirical and conceptual studies addressing this issue (Aguilar-Trigueros et al., 2015; Crowther et al., 2014; Dawson et al., 2018; Peay et al., 2008).

Wood-inhabiting fungi constitute a highly species-rich and functionally important group regulating nutrient cycling in forest ecosystems (Boddy et al., 2008; Dowding, 1981; Kahl et al., 2017; Stokland et al., 2012). Wood-inhabiting fungal communities strongly respond to changes in environmental variables such as climatic conditions (Bässler et al., 2010; Boddy and Heilmann-Clausen, 2008; Heilmann-Clausen et al., 2014; Heilmann-Clausen and Christensen, 2005; Lindblad, 2001; Pouska et al., 2017), resource quality (Abrego and Salcedo, 2013; Juutilainen et al., 2017; Küffer et al., 2008; Renvall, 1995) and habitat naturalness (Abrego and Salcedo, 2014; Bader et al., 1995; Lõhmus, 2011; Sippola et al., 2001; Sippola and Renvall, 1999). Given the strong responses of wood-inhabiting fungal communities to the environment and their high taxonomical and morphological diversity, many recent studies have focused on understanding how fungal functional diversity is influenced by environmental conditions (e.g. Abrego et al., 2017; Bässler et al., 2014; Caiafa et al., 2017; Calhim et al., 2018; Kauserud et al., 2011; Nordén et al., 2013; Norros et al., 2015). 
Traits related to spore and fruitbody morphology are among the very few traits that are comprehensively available for wood-inhabiting fungi (Dawson et al., 2018). In previous studies, these traits have been found to be important in determining the occurrences of fungal species on dead wood of different sizes and decay stages (Abrego et al., 2017; Nordén et al., 2013). In terms of fruitbody morphology, wood-inhabiting fungal species with robust pileate and resupinate fruitbodies have been found to require large dead wood (Abrego et al., 2017; Bässler et al., 2016), while fungi with ramarioid fruitbodies and resupinate polypores require strongly decayed wood (Abrego et al., 2017). In terms of spore morphology, dead wood in advanced decay stages harbours more wood-inhabiting fungal species with thick-walled and ornamented spores (Abrego et al., 2017). The links between spore size and dead wood characteristics, however, remain unresolved. Nordén et al. (2013) found that spore size slightly decreased as log size increased, while Abrego et al. (2017) discovered that larger logs hold species with somewhat larger spores. The discrepancy in the results between the cited studies most likely arises from the differences in the taxonomical coverage and host-tree species.

Host-tree identity is an important determinant of the species composition of woodinhabiting fungal communities (Krah et al., 2018b; Lumley et al., 2001; Ordynets et al., 2018; Rajala et al., 2010). In some cases, host-tree identity can determine wood-inhabiting fungal diversity more than microclimatic conditions and local dead wood amount or heterogeneity (Krah et al., 2018b). In general, broadleaved and coniferous dead trees hold quite distinct fungal communities, broadleaved trees being more species rich (Abrego et al., 2016; Rajala et al., 2010; Stokland, 2012a). According to Rajala et al. (2010), the higher species richness in broadleaved trees results from a higher diversity of Ascomycota. In spite of the clear influence of host-tree species on wood-inhabiting fungal community composition, to our knowledge, the effect of host tree identity on the functional composition of wood-inhabiting fungal 
communities has not been thoroughly investigated (but see Kauserud et al., 2008 for polypores).

Fennoscandian boreal forests represent a suitable ecosystem for studying the effect of host-tree identity on wood-inhabiting fungal communities. These forests are composed of a relatively small set of broadleaved and coniferous tree species, which all produce high amounts of dead wood (Esseen et al., 1997; Siitonen, 2001). In the southern boreal zone in Finland, (Ahti et al., 1968), the dominant tree species are Norway spruce (Picea abies, hereafter called spruce), Scots pine (Pinus sylvestris, pine), birches (Betula spp.) and European aspen (Populus tremula, aspen). While the fungal communities inhabiting dead spruce wood have been extensively studied (Edman et al., 2004; Kruys et al., 1999; Kubartová et al., 2012; Ottosson et al., 2015), the fungal communities inhabiting the other dominant tree species, especially birch and aspen, have been less studied (but see Lumley et al. 2001; Rajala et al. 2010; Ruokolainen et al. 2018).

The main aim of the present study is to evaluate how host-tree characteristics relate to the morphological composition of fruiting wood-inhabiting fungi. For this, we use an extensive dataset consisting of 657 species of non-lichenized fungi producing sexual fruitbodies. We surveyed large logs (base diameter $>15 \mathrm{~cm}$ ) belonging to the four dominant tree species in Fennoscandian boreal forests (spruce, pine, birch and aspen) in 12 seminatural forest sites. More specifically, we determine how much of the variation in species occurrences is explained by the host-tree species and volume, and how much of the variation in community composition is explained by the morphological characteristics of the fruitbodies and spores.

We expected differences in trait composition to arise from the differences in the wood composition and distributional patterns of coniferous versus broadleaved trees. Coniferous and broadleaved wood differ in their chemical and physical characteristics, coniferous wood having generally higher amounts of toxic compounds for saproxylic organisms (Stokland, 2012a). In 
terms of distributional patterns, in Finnish boreal forests broadleaved trees are less abundant and show more clumped distributions than coniferous trees. Thus, the fungal species growing on each of the wood types should be well adapted to colonize and exploit the wood resources accordingly.

We hypothesized that the manner by which species exploit the wood resources is reflected in the morphological traits, as these may be linked to resource-use and dispersal strategies. Our main working hypotheses related to fruitbody morphology are: 1) species producing small-sized fruitbodies, such as some Ascomycota, are most prevalent on broadleaved wood because unlike other fungi, they are able to decompose bark through soft rot, and bark is more abundant in decomposing broadleaved logs than in coniferous logs; 2) Agaricoids are most prevalent on broadleaved wood, because they have lignin-decomposing enzymes (causing white rot) which are especially efficient in exploiting wood of broadleaved trees (Krah et al., 2018a); 3) Species with pileate and resupinate fruitbodies are expected to be equally prevalent in broadleaved and coniferous logs, because these include lineages which equally well decompose cellulose and mostly occur on coniferous logs (i.e. brown-rot fungi), or mainly decompose lignin and mostly occur on broadleaved logs (i.e. white-rot fungi) (Krah et al., 2018a). Our working hypothesis about how spore morphology is linked to host tree is that 4) coniferous trees host species with smaller spores because their wood is easier to penetrate, compared to wood of broadleaved trees (Kauserud et al., 2008); and 5) broadleaved trees with clumped distributions in the forest landscape (e.g. aspen) also have species with small-sized spores, because they should be able to disperse longer distances (Norros et al., 2014).

\section{MATERIALS AND METHODS}




\section{Study sites and design}

We carried out the study in central Finland, which belongs to the southern boreal vegetation zone (Ahti et al., 1968). All of the 12 study sites were spruce dominated forests characterized by Myrtillus or Oxalis-Myrtillus forest types (Cajander, 1949). All study sites were seminatural, and varied relatively little in their age and management history. To control for the quality variation among the study sites in the analyses, we used a forest naturalness index described in Supplementary material 1 . From each forest, we chose four large (base diameter $\geq 15 \mathrm{~cm}$ ), naturally died, fallen logs of birch, spruce, pine and aspen (these species produce the majority of the coarse dead wood (diameter at breast height $>10 \mathrm{~cm}$ ) in the area), in total 16 logs at each site and $192 \operatorname{logs}$ in the whole study. To minimize the variation in log quality, only logs that had their decay stage between 2-4 (Renvall, 1995), and moss cover $<50 \%$ were selected. For each log, we measured the base and top diameter and the length of the logs, and calculated the volume by using the formula of a truncated cone.

\section{Fungal data collection and identification}

We thoroughly surveyed the fungal sexual fruitbodies on each study log. All fruitbodies from the same taxon within a study log were considered as one occurrence of the taxon. To better account for the species-specific variation in the timing and duration of fruitbody production (see Purhonen et al., 2017), two subsequent inspections were conducted for each log. The first inspection was performed between $21^{\text {st }}$ of May and $6^{\text {th }}$ of June, and the second between $20^{\text {th }}$ of August and $26^{\text {th }}$ of September. To enable multiple surveys of the same logs, moss and bark cover was left intact and the logs were not turned over. The fruitbodies were identified to species in the field or collected for microscopic identification (about 7500 specimens collected). When the species-level identification was not possible, we identified the specimens to the highest possible taxonomical level and named them with unique labels according to their 


\section{Fungal trait data collection}

The identified species were classified into seven groups according to their fruitbody morphology; agaricoids were species having a soft pileus and stipe (also pleurotoid fungi were grouped here). As discomycetoids, we classified species with disc- to cup-shaped fruitbodies. Pileates were species that grow as crusts over the log surface when young but majority of the fruitbody is a pileus or erected on the edges when adults. As pyrenomycetoids, we classified those fungi of which fruitbodies were organized in individual round or flask shaped bags (i.e. perithecia). Ramarioids had fruitbodies with branched structure. As resupinates, we classified those species that mostly grow as a crust over the log surface, but some may be slightly pileate as well. Stromatoids were fungi whose fruitbodies are organized round or flask shaped bags embedded in a hard mass-like structure.

For the spore morphology, we gathered information about spore length, width and presence of ornamentation (meaning that the surface of the spore is not smooth but has some texture) from the literature. For those specimens that we could only identify to the genus level, but still recognize as unique taxa, we measured the spore size and noted the shape during the identification procedure (see detailed description of the trait variable in Table 2.). The literature used for the spore morphology is listed in Supplementary Material 2.

To account for phylogenetic relationships between species, the phylogenetic relationships were estimated based on the taxonomic levels. As the data include a large number of poorly known species and species that are not yet described, it was not possible to use a quantitative phylogenetic tree. For each species, we included the taxonomic levels of the genus, 
family, order and class, using the Index Fungorum and Mycobank online databases (International Mycological Association, 2017; Royal Botanic Gardens Kew et al., 2017).

\section{Statistical analyses}

We analyzed the data with Hierarchical Modelling of Species Communities (HMSC; Ovaskainen et al., 2017). HMSC is a joint species distribution modelling framework (Warton et al., 2015) that enables the integration of data on species occurrences or abundances, environmental covariates, species traits and phylogenetic relationships, as well as the spatiotemporal nature of the study design (Ovaskainen et al., 2017).

In the HMSC analyses, the $n_{y} \times n_{S}$ response matrix $\mathbf{Y}$ consisted of presence-absences of the $n_{s}=657$ species observed in the $n_{y}=192 \operatorname{logs}$, called henceforth sampling units. We modelled $\mathbf{Y}$ with probit-regression, including in the predictor matrix $\mathbf{X}$ the environmental covariates of the tree species (categorical variable with four levels: aspen, birch, spruce and pine), the size of the dead wood unit (log-transformed volume), decay class (categorical variable with two levels: decay class 2; and decay classes 3 and 4 combined, as only four logs had decay class four), and the forest naturalness index. We modelled the mapping from $\mathbf{X}$ to $\mathbf{Y}$ as a function of species traits and phylogenetic relationships following Abrego et al. (2017) and Ovaskainen et al. (2017). We included in the matrix of species traits $\mathbf{T}$ the fruitbody morphology (categorical variable with seven levels: agaricoid, discomycetoid, pileate, pyrenomycetoid, ramarioid, resupinate, stromatoid), the presence of ornamentation in the spores (categorical variable with two levels: yes or no), spore shape (log-transformed ratio of length to width), and spore size (log-transformed volume). In the absence of a quantitative phylogeny, we followed Abrego et al. (2017) and used as a proxy for the phylogenetic correlation matrix $\mathbf{C}$ a taxonomical correlation matrix, constructed from the five levels of class, order, family, genus and species, and assumed equal branch length for each level. As a 
community-level random effect, implemented through a latent variable approach (Ovaskainen et al., 2017, 2016), we included the study site, with 12 levels.

We fitted the model to the data using the HMSC-R package (Tikhonov et al., 2019). We assumed the default prior distributions, and sampled the posterior distribution for $150 *$ thinning iterations, out of which the first $50 *$ thinning iterations were discarded as burn-in. We used thinning=100 and thus run the MCMC chain for a total of 15,000 iterations. We assessed the convergence of the MCMC chain visually, and examining the convergence of the results between thinning $=1$, thinning $=10$, and thinning $=100$.

To examine host-tree specialization at the levels of species and functional groups, we used the fitted model to predict species occurrences to new sampling units that were standardized to be of average size and decay stage and consisted of each of the four host-tree species. To examine host-tree specialization at the species level, we used these predictions to classify the host-tree use of each fungal species to one of the following seven classes: generalist, coniferous generalist, spruce specialist, pine specialist, broadleaved generalist, birch specialist, and aspen specialist. We first classified the species as generalists, broadleaved species or coniferous species by asking whether the predicted mean occurrence probability over broadleaved trees (birch and aspen) was smaller or greater than that for coniferous trees (pine and spruce) with at least $95 \%$ posterior probability. We further classified the broadleaved species as aspen specialists, birch specialists or broadleaved generalists by examining if the occurrence probability on aspen was smaller or greater than that for birch with at least $95 \%$ posterior probability. Similarly, we classified the coniferous species as spruce specialists, pine specialists and coniferous generalists.

To examine host-use specialization at the functional group level, we counted for each seven host-tree use classes the numbers of species belonging to each of the seven fruitbody types. We then asked if a particular fruitbody type was over- or underrepresented in a given 


\section{RESULTS}

\section{Morphological traits and species richness}

In total, we recorded 657 species in total, which occurred 5714 times (Appendix 1). A large proportion of the species was resupinates ( 288 species, $44 \%$ ), followed by discomycetes ( 148 , $22.5 \%)$, agaricoids $(73,11 \%)$, pyrenomycetoids $(71,11 \%)$, pileates $(49,7 \%)$, stromatoids $(18$, $3 \%)$, and ramarioids $(10,1.5 \%)$.

Aspen dead wood had the highest fungal species richness (239 spp.), followed by birch (221), spruce (209) and pine (186). All tree species shared 68 species, on top of which the two broadleaved species shared 107 species, the two conifers shared 70, whereas all other combinations of coniferous and broadleaved tree species shared less than 20 fungal species. Discomycetoids, pyrenomycetoids, ramarioids and stromatoids had significantly higher species richness on broadleaved host trees than on conifers (Supplementary Material 3).

Spore size (volume) and shape (length/width) showed a weak but statistically significant negative association (in linear regression, $p=0.02, \mathrm{R}^{2}=0.008$ ). While pyrenomycetoids had the largest and most elongated spores, agaricoids had large and spherical spores, whereas pileates and resupinates had the smallest spores (Fig. 1). 


\section{Effects of environmental variables on community composition}

The fitted joint species distribution model explained $6 \%$ of the variation in the fungal community composition, as measured by the average Tjur (2009) $\mathrm{R}^{2}$ value over the species. Of the variables included in the model, host-tree species was by far the most important one, as $71 \%$ of the explained variation in species occurrence was attributed to it. The percentages of explained variation attributed to other variables were $15 \%$ for log-characteristics (size and decay class), $5 \%$ for forest naturalness, and $9 \%$ for the random effect of the site. Considering only associations that had at least $95 \%$ posterior support, the occurrence probability of 86 species increased and of 0 species decreased with the size of the log, 16 species preferred decay class 3 and 11 species decay class 2, and the occurrence probability of 10 species increased and of 1 species decreased with the increasing value of the naturalness index.

Among the 293 species that occurred at least four times in the data, 66 were generalists, 95 broadleaved generalists, 30 birch specialists, 14 aspen specialists, 41 coniferous specialists, 27 spruce specialists and 20 pine specialists (Fig. 2).

\section{Effects of morphological traits on the responses to the environment}

The traits explained $7 \%$ of the variation in the species responses to the environmental variables. The posterior mean of the phylogenetic signal parameter $\rho$ was 0.20 and its $95 \%$ credibility interval was $[0.11,0.35]$. As the prior for $\rho$ has probability mass of 0.5 at $\rho=0$ (no phylogenetic signal) and the remaining probability is distributed evenly in $[0,1]$, the model revealed a moderate but statistically well supported phylogenetic signal in species responses to environmental covariates. In other words, phylogenetically (taxonomically) related species showed more similar responses to the environmental covariates than could be predicted solely based on their traits. We recorded a large number of non-random associations between hosttree use and fruitbody type (Fig. 3). In particular, species with resupinate fruitbodies were 


\section{DISCUSSION}

Our study shows that the occurrence of fungal species in dead wood of different characteristics relates to the morphological traits of the fungal fruitbodies and sexual spores. While it is well known that many wood-inhabiting fungal species are specialized to certain host-tree species (Berglund et al., 2011; Küffer et al., 2008; Stokland et al., 2004; Stokland, 2012a), to our knowledge, this is the first time that the importance of the fruitbody and spore morphology in determining host-tree specialization is revealed. We next discuss in turn, how and why fruitbody and spore morphology are linked to host-tree identity.

Specialization to host-tree species was related to fruitbody morphology. In line with our hypothesis that species developing small-sized fruitbodies from the Ascomycota lineages are more prevalent on broadleaved wood, we found discomycetes to be specialized to broadleaved trees in general, and pyrenomycetes to birch in particular. This association may relate to the 
fact that broadleaved dead wood generally holds higher proportions of bark, which is possible to decompose only through the so called soft-rot carried out by some Ascomycota species (Stokland, 2012b). While we expected species with pileate and resupinate fruitbodies to be equally prevalent in broadleaved and coniferous wood, we found resupinate species to be specialized to conifer tree species in general and pileates to spruce in particular. Because of the small-scale of our study (forests from central Finland), it remains to be tested by larger scale studies whether this is a general pattern in wood-inhabiting fungal communities.

Our results also revealed an association between host tree species and spore size. Fungal species on broadleaved trees had on average larger spores than those inhabiting conifers. This result is in line with Kauserud et al. (2008) who found that polypore species inhabiting broadleaved dead wood had significantly larger spores than species inhabiting coniferous dead wood. They speculated that because coniferous trees are evolutionary older, their wood is easier to penetrate and thus colonizing spores do not need as much energy and inoculum potential as spores colonizing broadleaved trees. Our results show that this may also relate to the relationship between fruitbody morphology and spore size, as pyrenomycetoids had on average the largest and most elongated spores, and they were also as a group specialized on broadleaved trees (birch in particular).

We expected aspen dead trees to hold species with smaller spores, because these trees show clustered and isolated distributional patterns in the boreal forest landscape, and smaller spores are able to disperse larger distances (Norros et al., 2014). Yet, our results showed the contrary, the fungal species occurring on broadleaved dead wood having on average larger, and more specifically more elongated, spores. Some studies have suggested that spore elongation increases attachment to substrate (Calhim et al., 2018; Ingold, 1965). It remains to be tested what is the primary reason pushing larger spore size on species inhabiting broadleaved trees. 
Considering the relationship between log characteristics and spore morphology, previous studies have reported weak and/or contrasting results (e. g. Nordén et al. 2013; Abrego et al. 2017). Interestingly, we found a clear relationship between spore size and shape and the log size. Species with spherical and large spores preferred large logs, whereas species with elongated and small spores preferred smaller logs. Bässler et al. (2014) hypothesized that wood-inhabiting fungal species with smaller and more elongated spores, follow the $r$ reproductive strategy (sensu Grime 1988), and thus cope better in managed environments where dead wood items are typically smaller. We cannot conclude how spore morphology relates to the $K / r$ reproductive strategy since we did not collect data about spore production. Yet, our results are in line with Bässler et al.'s (2014) hypothesis that species with smaller and more elongated spores occur more often in smaller dead trees; thus, their proportion can be expected to be higher in forests where most dead wood is small due to management actions (Abrego and Salcedo, 2013; Eräjää et al., 2010).

Spore ornamentation is not likely to influence airborne dispersal substantially (Hussein et al., 2013) but may be important for attaching to animal vectors for dispersal. Especially mycorrhizal species are characterized by ornamented spore walls (Halbwachs et al., 2015), which are suggested to aid in transportation to deeper soil layers via arthropod vectors (Calhim et al., 2018). As mycorrhizal species only utilize decaying logs for attaching their fruitbodies, it is logical that we did not find clear differences in spore ornamentation frequency between different tree species. However, the role of mycorrhizal fungi might be minor in the present study. The rationale is that the occurrence of mycorrhizal wood-inhabiting fungal species increases in the last decay stages (Mäkipää et al., 2017; Rajala et al., 2015), and our study included only intermediate decay stages. Moreover, the proportion of species with ornamented spores was equal in totally saprotrophic groups (ramarioids and stromatoids) and a group encompassing many mycorrhizal fungi (resupinates) (Kotiranta et al., 2009). However, we 
treated ornamentation as a bipartite yes/no variable although we acknowledge that there is a lot of variation within the different types of ornamentation and the role of different ornamentation types deserves more research attention.

We note that the vast majority of the variation in species occurrences at the level of logs was not explained by the fitted model. This result is in accordance with previous studies from temperate Europe (Abrego et al., 2017, 2014; Bässler et al., 2012), which concluded that random processes dominate in shaping wood-inhabiting fungal communities at small spatial scales. Most fungal species were rare (55\% occurring three or fewer times), which is a common feature of ecological communities in which random processes are dominating (Vellend, 2016; White et al., 2006). However, there might be many other variables we did not include, but which could have improved the models predictive power, such as microclimatic factors or direct measurements on wood composition such as $\mathrm{C} / \mathrm{N}$ ratio. This result was also partially influenced by the fact that we conducted only two surveys, one in each of the peak fruiting season in boreal forests (Abrego et al., 2016; Halme and Kotiaho, 2012; Purhonen et al., 2017). Since many wood-inhabiting fungi have ephemeral fruitbodies, repeating surveys over several years in the peak fruiting seasons would have decreased the proportion of rare species and thus increased the predictive power of our model. Also molecular surveys of mycelia would have possibly decreased the proportion of rare species and increased predictability of their occurrence (e.g. Kubartová et al. 2012; Mäkipää et al. 2017). However, in comparison to molecular surveys, fruitbody based surveys provide direct information about the "breeding" populations of fungi. As a large portion of the species groups in the present study is taxonomically poorly known, some of the results should be considered with caution. For example Mollisia sp., which were found to share several host-tree species, might indeed be specialized in different host trees (see also Runnel et al. 2014). 
We found that broadleaved dead trees hold higher species richness than coniferous dead trees. In particular, aspen hosted the highest and pine the lowest species richness. Higher species richness in broadleaved trees may result from the lack of defensive chemicals that conifer tree species have, making them easier to colonize and decay (Hoppe et al., 2016; Stokland, 2012a). However, fungal fruiting patterns may differ between tree species, and thus to observe the true differences in species richness between tree species, fruitbody surveys should be accompanied with molecular data of mycelia within wood. Furthermore, different tree species have different residence times, and thus the total species richness may be higher for tree species with longer life-span as a log.

\section{Conclusions}

Our study showed that the occurrence of fungal species in dead wood of different characteristics is related to the morphological traits of fungi. Our results also revealed that specialization to host-tree species occurs at the level of fruitbody morphological groups, and that the size and shape of the fungal spores relate to the preference for logs of different sizes.

\section{Acknowledgements}

We are grateful to Katja Juutilainen for contributing to the fungal surveys, Titta Kauppinen for help with dead wood and trait data collection and Leena Nikolajev-Wikström for trait data collection. Anni Rintoo, Jorma Pennanen, Matti Kulju, Unto Söderholm, Timo Kosonen and Tea von Bonsdorff helped with identification of difficult fungal specimens. We want to thank also Panu Kuokkanen from Metsähallitus for providing the forest age information of the study sites. We also thank the two anonymous reviewers for their constructive comments on an earlier version of the manuscript. This study was funded by the Ministry of the Environment (PUTTE 
grant to Halme), the Finnish Foundation of Nature Conversation and the Finnish Cultural Foundation (grants to Purhonen), Academy of Finland (grants 309581 and 284601 to Ovaskainen and grant 308651 to Nerea Abrego), Jane and Aatos Erkko Foundation (grant to Ovaskainen), and Research Council of Norway through its Centres of Excellence Funding Scheme (223257) to Ovaskainen via Centre for Biodiversity Dynamics.

\section{REFERENCES}

Abrego, N., García-Baquero, G., Halme, P., Ovaskainen, O., Salcedo, I., 2014. Community turnover of wood-inhabiting fungi across hierarchical spatial scales. PLoS One 9, e103416. https://doi.org/10.1371/journal.pone.0103416

Abrego, N., Halme, P., Purhonen, J., Ovaskainen, O., 2016. Fruit body based inventories in wood-inhabiting fungi: Should we replicate in space or time? Fungal Ecol. 20, 225-232. https://doi.org/10.1016/j.funeco.2016.01.007

Abrego, N., Norberg, A., Ovaskainen, O., 2017. Measuring and predicting the influence of traits on the assembly processes of wood-inhabiting fungi. J. Ecol. https://doi.org/10.1111/1365-2745.12722

Abrego, N., Salcedo, I., 2014. Response of wood-inhabiting fungal community to fragmentation in a beech forest landscape. Fungal Ecol. 8, 18-27. https://doi.org/10.1016/j.funeco.2013.12.007

Abrego, N., Salcedo, I., 2013. Variety of woody debris as the factor influencing woodinhabiting fungal richness and assemblages: Is it a question of quantity or quality? For. Ecol. Manage. 291, 377-385. https://doi.org/10.1016/j.foreco.2012.11.025

Aguilar-Trigueros, C.A., Hempel, S., Powell, J.R., Anderson, I.C., Antonovics, J., Bergmann, J., Cavagnaro, T.R., Chen, B., Hart, M.M., Klironomos, J., Petermann, J.S., Verbruggen, 
E., Veresoglou, S.D., Rillig, M.C., 2015. Branching out: Towards a trait-based understanding of fungal ecology. Fungal Biol. Rev. 29, 34-41. https://doi.org/10.1016/j.fbr.2015.03.001

Ahti, T., Hämet-Ahti, L., Jalas, J., 1968. Vegetation zones and their sections in northwestern Europe. Ann. Bot. Fenn. 5, 169-211.

Bader, P., Jansson, S., Jonsson, B.G., 1995. Wood-inhabiting fungi and substratum decline in selectively logged boreal spruce forests. Biol. Conserv. 72, 355-362. https://doi.org/10.1016/0006-3207(94)00029-P

Bässler, C., Ernst, R., Cadotte, M., Heibl, C., Müller, J., 2014. Near-to-nature logging influences fungal community assembly processes in a temperate forest. J. Appl. Ecol. 51, 939-948. https://doi.org/10.1111/1365-2664.12267

Bässler, C., Müller, J., Cadotte, M.W., Heibl, C., Bradtka, J.H., Thorn, S., Halbwachs, H., Forest, B., Park, N., Str, F., 2016. Functional response of lignicolous fungal guilds to bark beetle deforestation. Ecol. Indic. https://doi.org/10.1016/j.ecolind.2015.07.008

Bässler, C., Müller, J., Dziock, F., Brandl, R., 2010. Effects of resource availability and climate on the diversity of wood-decaying fungi. J. Ecol. 98, 822-832. https://doi.org/10.1111/j.1365-2745.2010.01669.x

Bässler, C., Müller, J., Svoboda, M., Lepšová, A., Hahn, C., Holzer, H., Pouska, V., 2012. Diversity of wood-decaying fungi under different disturbance regimes-A case study from spruce mountain forests. Biodivers. Conserv. 21, 33-49. https://doi.org/10.1007/s10531011-0159-0

Berglund, H., Hottola, J., Penttilä, R., Siitonen, J., 2011. Linking substrate and habitat requirements of wood-inhabiting fungi to their regional extinction vulnerability. Ecography (Cop.). 34, 864-875. https://doi.org/10.1111/j.1600-0587.2010.06141.x 
Boddy, L., Frankland, J.C., van West, P. (Eds.), 2008. Ecology of saprotrophic basidiomycetes. Elsevier Ltd, London.

Boddy, L., Heilmann-Clausen, J., 2008. Basidiomycete community development in temperate angiosperm wood, in: Boddy, L., Frankland, J.C., van West, P. (Eds.), Ecology of Saprotrophic Basidiomycetes. Elsevier, London, pp. 211-237.

Caiafa, M. V., Gómez-Hernández, M., Williams-Linera, G., Ramírez-Cruz, V., 2017. Functional diversity of macromycete communities along an environmental gradient in a Mexican seasonally dry tropical forest. Fungal Ecol. 28, 66-75. https://doi.org/10.1016/j.funeco.2017.04.005

Cajander, A.K., 1949. Forest types and their significance. Acta For. Fenn. 56, 1-69.

Calhim, S., Halme, P., Petersen, J.H., Læssøe, T., Bässler, C., Heilmann-Clausen, J., 2018. Fungal spore diversity reflects substrate-specific deposition challenges. Sci. Rep. 8, 1-9. https://doi.org/10.1038/s41598-018-23292-8

Crowther, T.W., Maynard, D.S., Crowther, T.R., Peccia, J., Smith, J.R., Bradford, M. a, 2014. Untangling the fungal niche: the trait-based approach. Front. Microbiol. 5, 579. https://doi.org/10.3389/fmicb.2014.00579

Dawson, S.K., Boddy, L., Halbwachs, H., Bässler, C., Crowther, T.W., Heilmann-Clausen, J., Nordén, J., Ovaskainen, O., Jönsson, M., 2018. Handbook for standardised measurement of macrofungal functional traits; a start with basidiomycete wood fungi. Funct. Ecol. doi: 10.1111/1365-2435.13239. https://doi.org/10.1111/1365-2435.13239

Dowding, P., 1981. Nutrient uptake and allocation during substrate exploitation by fungi, in: Wicklow, D.T., Carroll, G.C. (Eds.), The Fungal Community. Its Organization and Role in the Ecosystems. Marcel Dekker Inc, New York, pp. 612-636.

Edman, M., Kruys, N., Jonsson, B.G., 2004. Local Dispersal Sources Strongly Affect Colonization Patterns of Wood-Decaying Fungi on Spruce Logs. Ecol. Appl. 14, 893- 
901.

Eräjää, S., Halme, P., Kotiaho, J.S., Markkanen, A., Toivanen, T., 2010. The volume and composition of dead wood on traditional and forest fuel harvested clear-cuts. Silva Fenn. 44, 203-211. https://doi.org/10.14214/sf.150

Esseen, P.A., Ehnström, B., Ericson, L., Sjöberg, K., 1997. Boreal forests. Ecol. Bull. 46, 1647.

Grime, J.P., 1988. The C-S-R model of primary plant strategies - origins, implications and tests, in: Gottlieb, L.D., Jain, S. (Eds.), Plant Evolutionary Biology. Chapman and Hall, London, pp. 371-393.

Halbwachs, H., Brandl, R., Bässler, C., 2015. Spore wall traits of ectomycorrhizal and saprotrophic agarics may mirror their distinct lifestyles. Fungal Ecol. 17, 197-204. https://doi.org/10.1016/j.funeco.2014.10.003

Halme, P., Kotiaho, J.S., 2012. The importance of timing and number of surveys in fungal biodiversity research. Biodivers. Conserv. 21, 205-219. https://doi.org/10.1007/s10531011-0176-z

Heilmann-Clausen, J., Aude, E., van Dort, K., Christensen, M., Piltaver, A., Veerkamp, M., Walleyn, R., Siller, I., Standovár, T., Ódor, P., 2014. Communities of wood-inhabiting bryophytes and fungi on dead beech logs in Europe - reflecting substrate quality or shaped by climate and forest conditions? J. Biogeogr. 41, 2269-2282. https://doi.org/10.1111/jbi.12388

Heilmann-Clausen, J., Christensen, M., 2005. Wood-inhabiting macrofungi in Danish beechforests? conflicting diversity patterns and their implications in a conservation perspective. Biol. Conserv. 122, 633-642. https://doi.org/10.1016/j.biocon.2004.10.001

Hoppe, B., Purahong, W., Wubet, T., Kahl, T., Bauhus, J., Arnstadt, T., Hofrichter, M., Buscot, F., Krüger, D., 2016. Linking molecular deadwood-inhabiting fungal diversity and 
community dynamics to ecosystem functions and processes in Central European forests. Fungal Divers. 77, 367-379. https://doi.org/10.1007/s13225-015-0341-x

Hussein, T., Norros, V., Hakala, J., Petäjä, T., Aalto, P.P., Rannik, Ü., Vesala, T., Ovaskainen, O., 2013. Species traits and inertial deposition of fungal spores. J. Aerosol Sci. 61, 81-98. https://doi.org/10.1016/j.jaerosci.2013.03.004

Ingold, C.T., 1965. Spore liberation. Oxford University Press, Oxford.

International Mycological Association, 2017. Mycobank [WWW Document]. http://www.mycobank.org/.

Juutilainen, K., Mönkkönen, M., Kotiranta, H., Halme, P., 2017. Resource use of woodinhabiting fungi in different boreal forest types. Fungal Ecol. 27, 96-106. https://doi.org/10.1016/j.funeco.2017.03.003

Kahl, T., Arnstadt, T., Baber, K., Bässler, C., Bauhus, J., Borken, W., Buscot, F., Floren, A., Heibl, C., Hessenmöller, D., Hofrichter, M., Hoppe, B., Kellner, H., Krüger, D., Linsenmair, K.E., Matzner, E., Otto, P., Purahong, W., Seilwinder, C., Schulze, E.D., Wende, B., Weisser, W.W., Gossner, M.M., 2017. Wood decay rates of 13 temperate tree species in relation to wood properties, enzyme activities and organismic diversities. For. Ecol. Manage. 391, 86-95. https://doi.org/10.1016/j.foreco.2017.02.012

Kauserud, H., Colman, J.E., Ryvarden, L., 2008. Relationship between basidiospore size, shape and life history characteristics: a comparison of polypores. Fungal Ecol. 1, 19-23. https://doi.org/10.1016/j.funeco.2007.12.001

Kauserud, H., Heegaard, E., Halvorsen, R., Boddy, L., Høiland, K., Chr. Stenseth, N., 2011. Mushroom's spore size and time of fruiting are strongly related: Is moisture important? Biol. Lett. 7, 273-276. https://doi.org/10.1098/rsbl.2010.0820

Kotiranta, H., Saarenoksa, R., Kytövuori, I., 2009. Aphyllophoroid fungi of Finland. A checklist with ecology, distribution, and threat categories. Norrlinia 19, 1-223. 
Krah, F.S., Bässler, C., Heibl, C., Soghigian, J., Schaefer, H., Hibbett, D.S., 2018a. Evolutionary dynamics of host specialization in wood-decay fungi. BMC Evol. Biol. 18, 1-13. https://doi.org/10.1186/s12862-018-1229-7

Krah, F.S., Seibold, S., Brandl, R., Baldrian, P., Müller, J., Bässler, C., 2018b. Independent effects of host and environment on the diversity of wood-inhabiting fungi. J. Ecol. 1-15. https://doi.org/10.1111/1365-2745.12939

Kruys, N., Fries, C., Jonsson, B.G., Lämås, T., Ståhl, G., 1999. Wood-inhabiting cryptogams on dead Norway spruce (Picea abies) trees in managed Swedish boreal forests. Can. J. For. Res. 29, 178-186. https://doi.org/10.1139/x98-191

Kubartová, A., Ottosson, E., Dahlberg, A., Stenlid, J., 2012. Patterns of fungal communities among and within decaying logs, revealed by 454 sequencing. Mol. Ecol. 21, 4514-4532. https://doi.org/10.1111/j.1365-294X.2012.05723.x

Küffer, N., Gillet, F., Senn-Irlet, B., Aragno, M., Job, D., 2008. Ecological determinants of fungal diversity on dead wood in European forests. Fungal Divers. 30, 83-95.

Lindblad, I., 2001. Diversity of poroid and some corticoid wood-inhabiting fungi along the rainfall gradient in tropical forests, Costa Rica. J. Trop. Ecol. 17, 353-369.

Lõhmus, A., 2011. Silviculture as a disturbance regime: The effects of clear-cutting, planting and thinning on polypore communities in mixed forests. J. For. Res. 16, 194-202. https://doi.org/10.1007/s10310-011-0256-7

Lumley, T.C., Gignac, L.D., Currah, R.S., 2001. Microfungus communities of white spruce and trembling aspen logs at different stages of decay in disturbed and undisturbed sites in the boreal mixedwood region of Alberta. Can. J. Bot. 79, 76-92. https://doi.org/10.1139/cjb-79-1-76

Mäkipää, R., Rajala, T., Schigel, D., Rinne, K.T., Pennanen, T., Abrego, N., Ovaskainen, O., 2017. Interactions between soil- and dead wood-inhabiting fungal communities during the 
decay of Norway spruce logs. ISME J. 11, 1964-1974. https://doi.org/10.1038/ismej.2017.57

McGill, B.J., Enquist, B.J., Weiher, E., Westoby, M., 2006. Rebuilding community ecology from functional traits. Trends Ecol. Evol. 21, 178-185. https://doi.org/10.1016/j.tree.2006.02.002

Nordén, J., Penttilä, R., Siitonen, J., Tomppo, E., Ovaskainen, O., 2013. Specialist species of wood-inhabiting fungi struggle while generalists thrive in fragmented boreal forests. J. Ecol. 101, 701-712. https://doi.org/10.1111/1365-2745.12085

Norros, V., Karhu, E., Nordén, J., Vähätalo, A. V., Ovaskainen, O., 2015. Spore sensitivity to sunlight and freezing can restrict dispersal in wood-decay fungi. Ecol. Evol. 5, 33123326. https://doi.org/10.1002/ece3.1589

Norros, V., Rannik, Ü., Hussein, T., Petäjä, T., Vesala, T., Ovaskainen, O., 2014. Do small spores disperse further than large spores? Ecology 95, 1612-1621. https://doi.org/10.1890/13-0877.1

Ordynets, A., Heilmann-Clausen, J., Savchenko, A., Bässler, C., Volobuev, S., Akulov, O., Karadelev, M., Kotiranta, H., Saitta, A., Langer, E., Abrego, N., 2018. Do plant-based biogeographical regions shape aphyllophoroid fungal communities in Europe? J. Biogeogr. 45, 1182-1195. https://doi.org/10.1111/jbi.13203

Ottosson, E., Kubartova, A., Edman, M., Jönsson, M., Lindhe, A., Stenlid, J., Dahlberg, A., 2015. Diverse ecological roles within fungal communities in decomposing logs of Picea abies. FEMS Microbiol. Ecol. 91, 1-13. https://doi.org/10.1093/femsec/fiv012

Ovaskainen, O., Abrego, N., Halme, P., Dunson, D., 2016. Using latent variable models to identify large networks of species-to-species associations at different spatial scales. Methods Ecol. Evol. 7, 549-555. https://doi.org/10.1111/2041-210X.12501

Ovaskainen, O., Tikhonov, G., Norberg, A., Guillaume Blanchet, F., Duan, L., Dunson, D., 
Peay, K.G., Kennedy, P.G., Bruns, T.D., 2008. Fungal community ecology: A hybrid beast with a molecular master. Bioscience 58, 799-810.

Pouska, V., Macek, P., Zíbarová, L., Ostrow, H., 2017. How does the richness of wooddecaying fungi relate to wood microclimate? Fungal Ecol. 27, 178-181. https://doi.org/10.1016/j.funeco.2016.06.006

Purhonen, J., Huhtinen, S., Kotiranta, H., Kotiaho, J.S., 2017. Detailed information on fruiting phenology provides new insights on wood-inhabiting fungal detection. Fungal Ecol. 27, 175-177. https://doi.org/10.1016/j.funeco.2016.06.007

Rajala, T., Peltoniemi, M., Pennanen, T., Mäkipää, R., 2010. Relationship between woodinhabiting fungi determined by molecular analysis (denaturing gradient gel electrophoresis) and quality of decaying logs. Can. J. For. Res. 40, 2384-2397. https://doi.org/10.1139/X10-176

Rajala, T., Tuomivirta, T., Pennanen, T., Mäkipää, R., 2015. Habitat models of woodinhabiting fungi along a decay gradient of Norway spruce logs. Fungal Ecol. 18, 48-55. https://doi.org/10.1016/j.funeco.2015.08.007

Renvall, P., 1995. Community structure and dynamics of wood-rotting Basidiomycetes on decomposing conifer trunks in northern Finland. Karstenia 35, 1-51.

Royal Botanic Gardens Kew, Landcare Research-NZ, Chinese Academy of Science, 2017. Index fungorum [WWW Document]. www.indexfungorum.org.

Royal Botanic Gardens Kew, Landcare Research-NZ, Chinese Academy of Science, 2015. Index Fungorum [WWW Document]. www.indexfungorum.org.

Runnel, K., Põldmaa, K., Lõhmus, A., 2014. “Old-forest fungi” are not always what they seem: 
The case of Antrodia crassa. Fungal Ecol. 9, 27-33. https://doi.org/10.1016/j.funeco.2014.02.006

Ruokolainen, A., Shorohova, E., Penttilä, R., Kotkova, V., Kushnevskaya, H., 2018. A continuum of dead wood with various habitat elements maintains the diversity of woodinhabiting fungi in an old-growth boreal forest. Eur. J. For. Res. https://doi.org/10.1007/s10342-018-1135-y. https://doi.org/10.1007/s10342-018-1135-y

Siitonen, J., 2001. Forest management, coarse woody debris and saproxylic organisms: Fennoscandian boreal forests as an example. Ecol. Bull. 49, 11-41.

Sippola, A.-L., Lehesvirta, T., Renvall, P., 2001. Effect of selective logging on coarse woody debris and diversity of wood-decaying polypores in eastern Finland. Ecol. Bull. 49, 243254.

Sippola, A.L., Renvall, P., 1999. Wood-decomposing fungi and seed-tree cutting: A 40-year perspective. For. Ecol. Manage. 115, 183-201. https://doi.org/10.1016/S03781127(98)00398-3

Stokland, J.N., 2012a. Host-tree associattions, in: Stokland, J.N., Siitonen, J., Jonsson, B.G. (Eds.), Biodiversity in Dead Wood. Cambridge University Press, Cambridge, pp. 82-109. Stokland, J.N., 2012b. Wood decomposition, in: Stokland, J.N., Siitonen, J., Jonsson, B.G. (Eds.), Biodiversity in Dead Wood. Cambridge University Press, Cambridge, pp. 10-28. Stokland, J.N., Siitonen, J., Jonsson, B.G., 2012. Biodiversity on dead wood. Cambridge University Press, Cambridge.

Stokland, J.N., Tomter, S.M., Söderberg, U., 2004. Development of dead wood indicators for biodiversity monitoring: experiences from Scandinavia, in: Marchetti, M. (Ed.), Monitoring and Indicators of Forest Biodiversity in Europe, from Ideas to Operationality. EFI-Proceedings No. 51, pp. 207-226.

Tikhonov, G., Opedal, Ø., Lehikoinen, A., Ovaskainen, O., 2019. Joint species distribution 
modelling with HMSC-R. bioRxiv.

Tjur, T., 2009. Coefficients of determination in logistic regression models - A new proposal: The coefficient of discrimination. Am. Stat. 63, 366-372. https://doi.org/10.1198/tast.2009.08210

Vellend, M., 2016. The theory of ecological communities. Princeton University Press, New Jersey.

Warton, D.I., Blanchet, F.G., O’Hara, R.B., Ovaskainen, O., Taskinen, S., Walker, S.C., Hui, F.K.C., 2015. So Many Variables: Joint Modeling in Community Ecology. Trends Ecol. Evol. 30, 766-779. https://doi.org/10.1016/j.tree.2015.09.007

Weiher, E., Freund, D., Bunton, T., Stefanski, A., Lee, T., Bentivenga, S., 2011. Advances, challenges and a developing synthesis of ecological community assembly theory. Philos. Trans. R. Soc. B Biol. Sci. 366, 2403-2413. https://doi.org/10.1098/rstb.2011.0056

White, E.P., Adler, P.B., Lauenroth, W.K., Gill, R.A., Greenberg, D., Kaufman, D.M., Rassweiler, A., Rusak, J.A., Smith, M.D., Steinbeck, J.R., Waide, R.B., Yao, J., 2006. A comparison of the species time relationship across ecosystems and taxonomic groups. Oikos 112, 185-195. https://doi.org/10.1111/j.0030-1299.2006.14223.x

Figure captions:

Fig. 1 Relationship between spore morphological traits and fruitbody types. The relationship between (A) the fruitbody type and spore volume, (B) spore shape, (C) and spore ornamentation.

Fig. 2 Numbers of host-tree generalist and specialist fungal species. The bars show the numbers of fungal species classified to the seven host-tree specialization classes, with colours representing different fruitbody types. Note that the figure includes only those species that 
Fig. 3 Host-tree specialization-level of fungi with different fruitbody types. Green colours (respectively, red colours) indicate that the fungal species groups have a given host-tree classification more often (respectively, less often) than expected by random, the asterisks indicating those results that are supported by at least $95 \%$ posterior probability. Note that this analysis is restricted to those species that occur at least 4 times in the data.

Fig. 4 Community-weighted mean spore trait values for different host-tree species (panels AC) and for logs of different sizes (panels D-F). The first column shows the mean spore volume, the second column shows the mean spore shape, and the third column shows the mean proportions of species with ornamented spores. The error bars (panels A-C) and shaded areas (panels D-F) show the $95 \%$ credibility interval. 

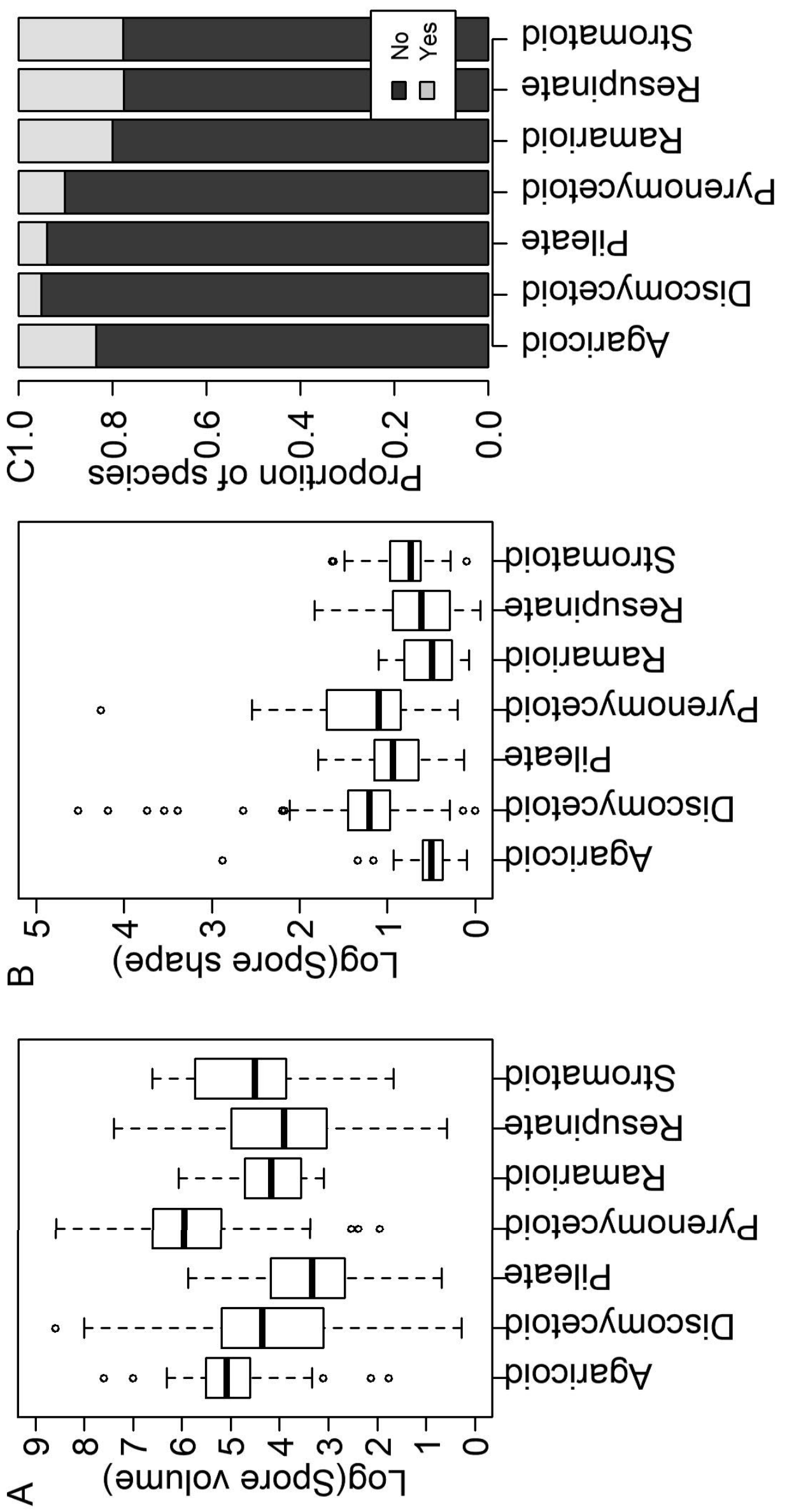


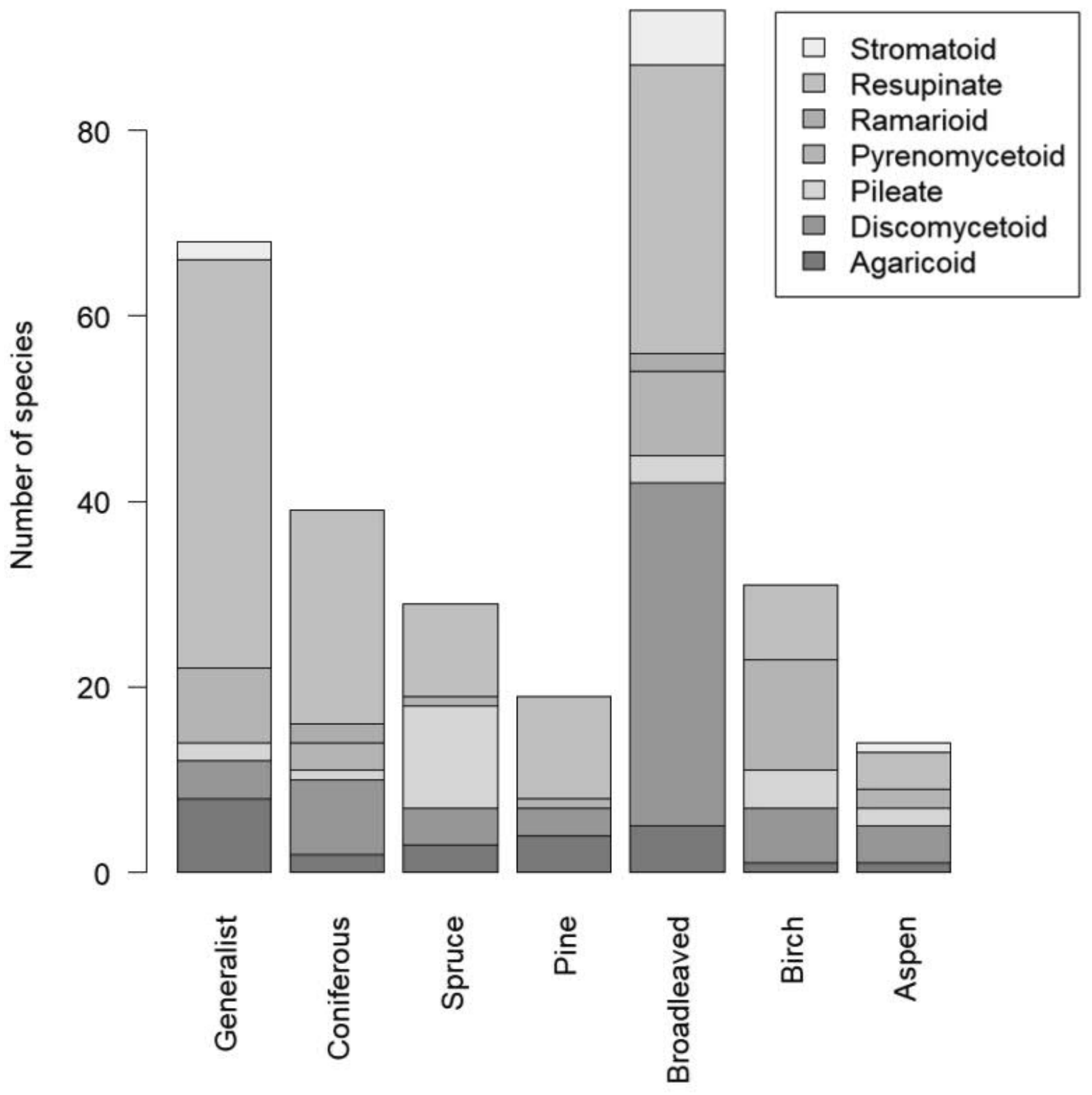




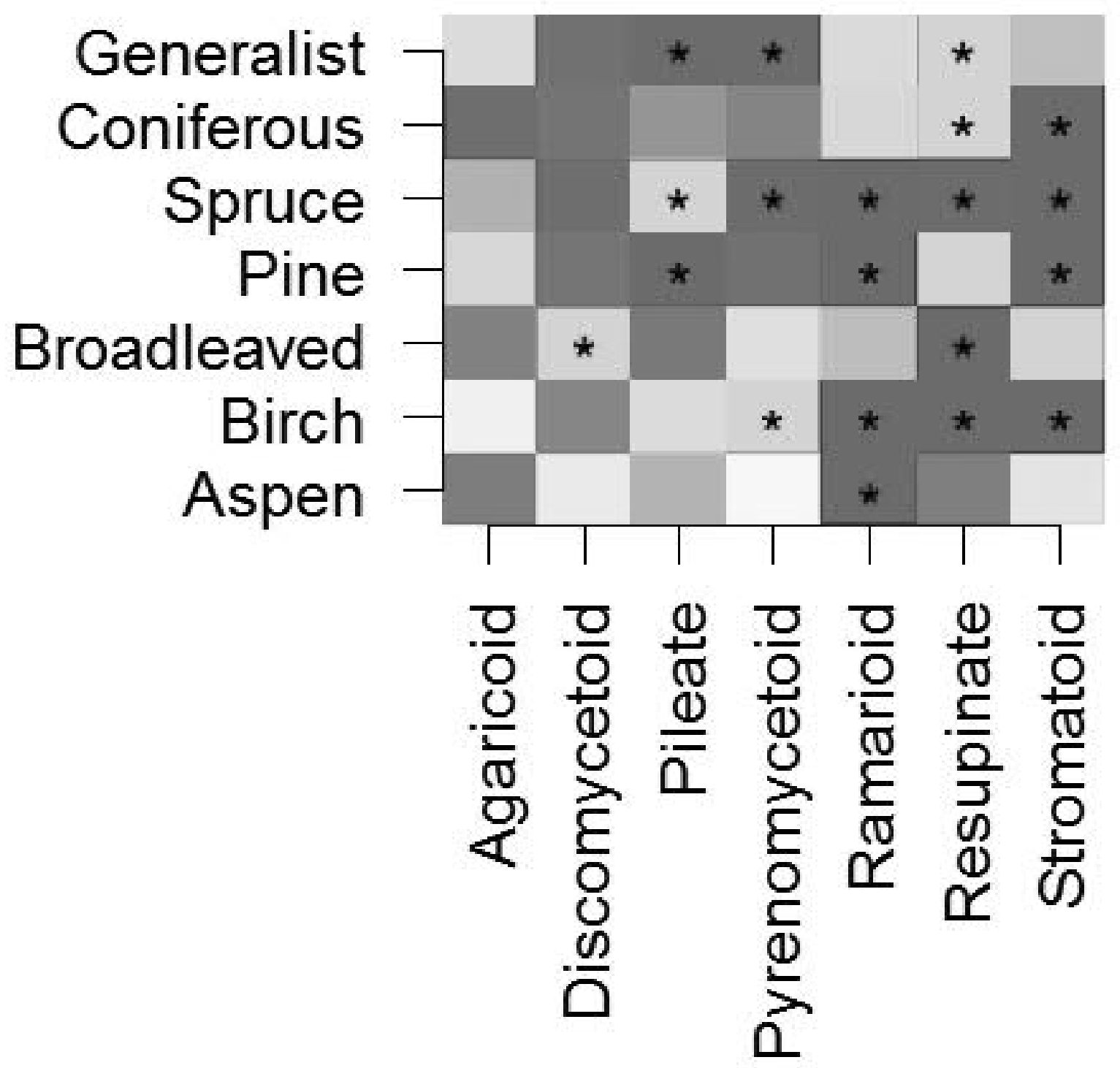




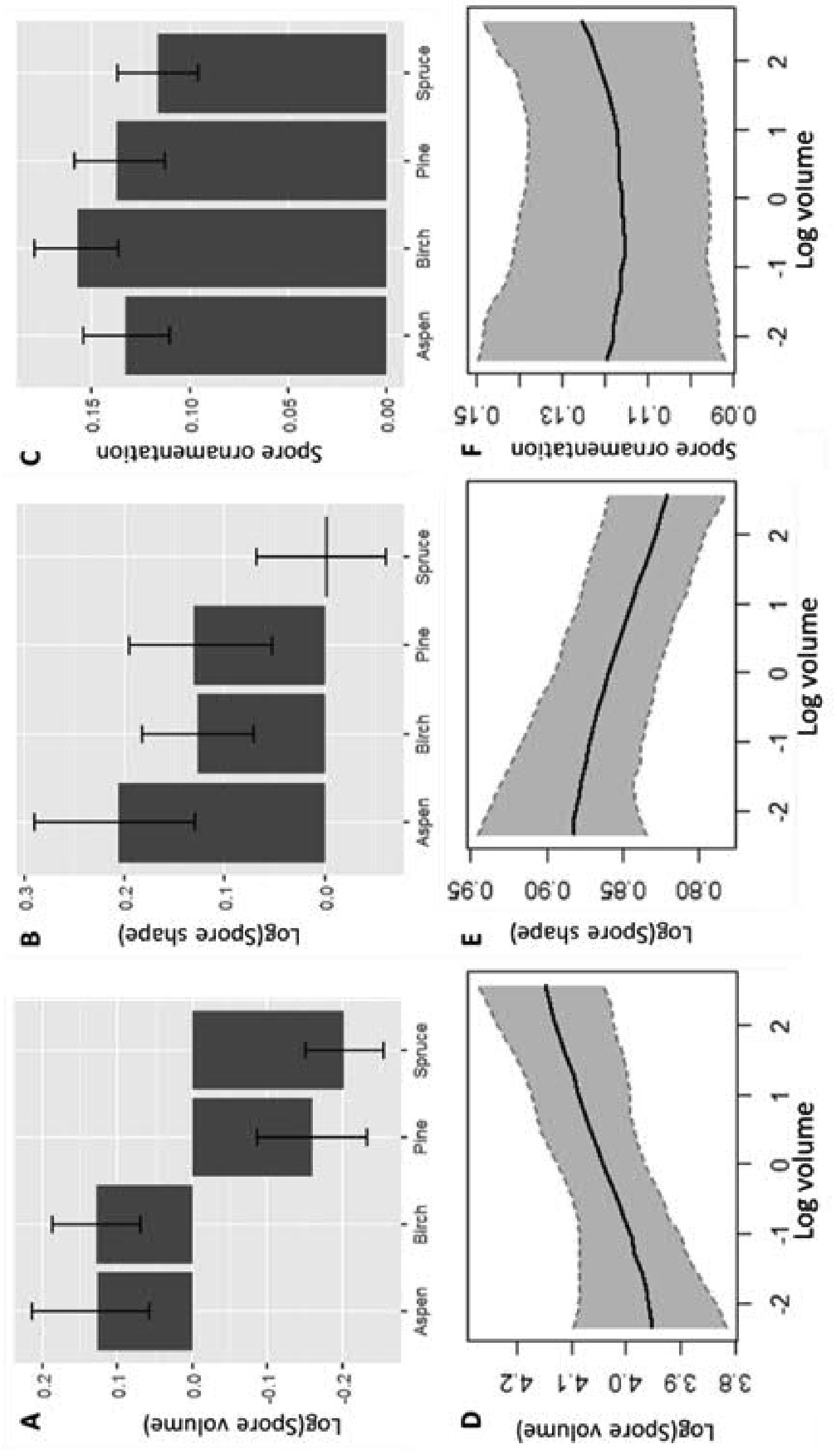




\section{Morphological traits predict host-tree specialization in wood-inhabiting fungal communities}

Purhonen Jenna, Ovaskainen Otso, Halme Panu, Komonen Atte, Huhtinen Seppo, Kotiranta

Heikki, Læssøe Thomas, \& Abrego Nerea

Supplementary Material 1

Detailed description of the forest naturalness index

The study site naturalness was calculated based on the average age of the dominating forest cover (data received from the State Forest Enterprise of Finland), the average amount of dead wood per hectare, and the average number of stumps per hectare. The dead wood and stump data were collected from four to eight, 50 meter in length and 10 meter wide, randomly placed transects. The transects were situated in the same forest stands in which the logs were surveyed for fungi. The number of transects varied depending on the characteristics of the study site. If there was clear within-site variation in the forest types surrounding the study logs, we established 2-4 additional transects. The transects were inspected for all dead wood units larger than $15 \mathrm{~cm}$ at the base. We measured the length, base diameter and top diameter (this information was later used for calculating the volume of the dead wood with the formula of a truncated cone) for standing and grounded dead wood. We also recorded the number of stumps. Transect data was then used to count average values for each of the variables at the transect level. We divided these values by 0.05 for estimating the average values per hectare. The sites were then sorted according to each of the above variable separately and a score from 1 to 12 was given depending on the site position. Sites with higher average age, more dead wood and fewer stumps were given more points and considered being more natural. The points of each forest were summed up to form the "forest naturalness index" (Table 1).

Table 1 The age of dominating forest cover in years and amount of deadwood $\left(\mathrm{m}^{3} / \mathrm{ha}\right)$ and number of stumps per hectare for each study site. Corresponding naturalness index-value for each site is the sum of the points. The sites are sorted according to their Index-values from most natural to least.

\begin{tabular}{llll}
\hline Site & Age / Deadwood / Stumps & Points & Index \\
\hline Latokuusikko & $173 / 334 / 0$ & $11 / 12 / 12$ & 35 \\
Pyhä-Häkki & $272 / 98 / 39$ & $12 / 9 / 11$ & 32 \\
Kalajanvuori & $140 / 100 / 64$ & $9 / 10 / 10$ & 29 \\
Kuusimäki & $140 / 171 / 110$ & $8 / 11 / 6$ & 25 \\
Kivetty & $132 / 86 / 103$ & $6 / 8 / 8$ & 22 \\
Lortikka & $150 / 32 / 96$ & $10 / 1 / 9$ & 20 \\
Leivonmäki & $135 / 67 / 135$ & $7 / 6 / 4$ & 17 \\
Ilmakkamäki & $124 / 65 / 117$ & $5 / 5 / 5$ & 15 \\
Vuorilampi & $116 / 81 / 199$ & $3 / 7 / 3$ & 13 \\
Vaarunvuori & $104 / 37 / 106$ & $2 / 2 / 7$ & 11 \\
Hallinmäki & $119 / 59 / 259$ & $4 / 3 / 2$ & 9 \\
Tikkamäki & $84 / 60 / 303$ & $1 / 4 / 1$ & 6 \\
\hline
\end{tabular}




\section{Morphological traits predict host-tree specialization in wood-inhabiting fungal communities}

Purhonen Jenna, Ovaskainen Otso, Halme Panu, Komonen Atte, Huhtinen Seppo, Kotiranta Heikki, Læssøe Thomas, \& Abrego Nerea

Supplementary material 2

TABLE 1 List of detected species or taxonomic groups in alphabetical order. The trait data are shown for fruitbody type (7 categories, see Methods), spore volume $\left(\mu \mathrm{m}^{3}\right.$, calculated with the formula of using species-specific mean spore length and width), shape (species-specific mean length of the spore divided by its width) and ornamentation (Yes, No). The information was extracted from literature (below) or by measuring/ observing by the authors.

\begin{tabular}{|c|c|c|c|c|c|c|c|c|c|}
\hline Species or taxa name & Fruit body type & Volume & Shape & Orn & Birch & Spruce & Pine & Aspen & Total \\
\hline Acanthostigma sp1. & Pyrenomycetoid & 96.40 & 2.24 & No & - & 1 & - & 1 & 2 \\
\hline Acrogenospora carmichaeliana & Pyrenomycetoid & 1948.28 & 2.14 & No & - & - & - & 1 & 1 \\
\hline Actidium hysterioides & Pyrenomycetoid & 57.65 & 6.44 & No & - & 12 & 1 & - & 13 \\
\hline Alutaceodontia alutacea & Resupinate & 14.97 & 4.24 & No & - & 8 & 3 & 2 & 13 \\
\hline Amphinema byssoides & Resupinate & 22.09 & 1.80 & No & 37 & 19 & 2 & 34 & 92 \\
\hline Amphisphaerella dispersella & Pyrenomycetoid & 1526.81 & 2.67 & No & - & - & - & 1 & 1 \\
\hline Amphisphaeria bertiana & Pyrenomycetoid & 174.95 & 2.44 & No & 1 & - & - & - & 1 \\
\hline $\begin{array}{l}\text { Amylocorticiellum } \\
\text { cremeoisabellinum }\end{array}$ & Resupinate & 57.73 & 1.71 & No & - & - & - & 1 & 1 \\
\hline $\begin{array}{l}\text { Amylocorticiellum } \\
\text { subillaqueatum }\end{array}$ & Resupinate & 15.90 & 1.78 & No & - & - & - & 1 & 1 \\
\hline Amylocorticium cebennence & Resupinate & 26.84 & 3.00 & No & - & 1 & 1 & - & 2 \\
\hline Amylocorticium pedunculatum & Resupinate & 37.33 & 1.38 & No & - & - & 1 & - & 1 \\
\hline Amylocystis lapponica & Pileate & 53.31 & 2.64 & No & - & 3 & - & - & 3 \\
\hline Amyloporia sinuosa & Resupinate & 10.96 & 3.41 & No & - & 9 & 13 & - & 22 \\
\hline Amylostereum chailletii & Pileate & 41.58 & 2.55 & No & - & 7 & - & 1 & 8 \\
\hline Amyloxenasma grisellum & Resupinate & 32.67 & 2.00 & No & - & 2 & 1 & 2 & 5 \\
\hline Annulohypoxylon multiforme & Stromatoid & 177.21 & 2.11 & No & 12 & - & - & 8 & 20 \\
\hline Antrodia albobrunnea & Resupinate & 11.23 & 3.18 & No & - & - & 1 & - & 1 \\
\hline Antrodia macra & Resupinate & 96.26 & 2.52 & No & - & - & - & 3 & 3 \\
\hline Antrodia pulvinascens & Resupinate & 52.60 & 2.14 & No & - & - & - & 1 & 1 \\
\hline Antrodia serialis & Pileate & 40.09 & 2.45 & No & - & 39 & 1 & - & 40 \\
\hline Antrodia xantha & Resupinate & 7.27 & 3.03 & No & - & 1 & 9 & - & 10 \\
\hline Antrodiella pallescens & Resupinate & 10.21 & 1.89 & No & 1 & - & - & - & 1 \\
\hline Antrodiella romellii & Resupinate & 14.91 & 1.67 & No & 2 & - & - & - & 2 \\
\hline Aphanobasidium pseudotsugae & Resupinate & 71.79 & 1.73 & No & - & 11 & 25 & - & 36 \\
\hline Arachnopeziza aurata & Discomycetoid & 199.69 & 29.51 & No & 17 & - & - & 11 & 28 \\
\hline Arachnopeziza cf aranea & Discomycetoid & 58.90 & 4.80 & No & 1 & - & - & 1 & 2 \\
\hline Arachnopeziza cornuta & Discomycetoid & 50.31 & 4.94 & No & 15 & - & - & 18 & 33 \\
\hline
\end{tabular}


Arachnopeziza joannea

Arachnopeziza sp nov

Arachnopeziza sp1.

Arachnopeziza sp3.

Armillaria borealis

Arrhenia epichysium

Artomyces cristatus

Artomyces pyxidatus

Ascocorticium anomalum

Ascocoryne cylichnium

Ascocoryne sarcoides

Asterodon ferruginosus

Asterostroma laxum

Athelia acrospora

Athelia decipiens

Athelia epiphylla coll

Athelia neuhoffii

Athelopsis glaucina

Athelopsis subinconspicua

Auricularia auricula-judae

Basidiodendron caesiocinereum

Basidiodendron cinereum

Basidioradulum crustosum

Bertia moriformis

Bisporella citrina

Bjerkandera adusta

Boidinia furfuracea

Bolbitius reticulatus

Boliniaceae sp1.

Botryobasidium botryosum

Botryobasidium conspersum

Botryobasidium intertextum

Botryobasidium laeve

Botryobasidium medium

Botryobasidium obtusisporum

Botryobasidium subcoronatum
Discomycetoid

Discomycetoid

Discomycetoid

Discomycetoid

Agaricoid

Agaricoid

Ramarioid

Ramarioid

Resupinate

Discomycetoid

Discomycetoid

Resupinate

Resupinate

Resupinate

Resupinate

Resupinate

Resupinate

Resupinate

Resupinate

Discomycetoid

Resupinate

Resupinate

Resupinate

Pyrenomycetoid

Discomycetoid

Pileate

Resupinate

Agaricoid

Pyrenomycetoid

Resupinate

Resupinate

Resupinate

Resupinate

Resupinate

Resupinate

Resupinate
71.57

4.63 No

$105.85 \quad 4.84 \quad$ No

$226.19 \quad 4.50 \quad$ No

88.36

$4.17 \mathrm{No}$

152.17

1.55 No

106.40

1.76 No

288.63

22.30

1.07 No

10.22

1.62 Yes

2.43 No

$\begin{array}{lll}571.28 & 3.83 \quad \text { No }\end{array}$

$238.56 \quad 3.33 \quad$ No

$75.40 \quad 1.50 \quad$ No

$269.39 \quad 1.00 \quad$ Yes

$\begin{array}{lll}37.12 & 2.27 & \text { No }\end{array}$

39.40

1.46 No

292.13

1.96 No

124.04

1.47 No

37.77

4.22 No

99.30

1.65 No

221.51

2.63 No

453.96

0.94 Yes

365.60

1.36 No

32.67

$2.00 \quad$ No

1038.69

6.96 No

85.53

3.03 No

28.21

$1.73 \mathrm{No}$

98.17

1.00 Yes

$168.35 \quad 2.00 \quad$ No

72.55

$2.50 \quad$ No

99.40

$2.40 \quad \mathrm{No}$

47.52

2.91 No

25.92

4.13 No

53.92

2.00 Yes

249.46

1.91 No

177.21

2.11 No

40.09

$2.45 \mathrm{~N}$

26

32

27

20

105 
Botryohypochnus isabellinus

Butyrea luteoalbum

Byssomerulius corium

Byssoporia terrestris

Cabalodontia bresadolae

Cabalodontia cretacea

Cabalodontia subcretacea

Calocera cornea

Calocera furcata

Calocera viscosa

Calycellina guttulifera

Calycellina ochracea

Calycellina sp1.

Calyptella sp1.

Camarops lutea/pugillus complex

Camarops tubulina

Capitotricha bicolor

Capronia cf mansonii

Capronia cf pilosella

Capronia cf semi-immersa

Capronia sp4.

Capronia sp5.

Ceraceomyces eludens

Ceraceomyces microsporus

Ceraceomyces serpens

Ceraceomyces tessulatus

Ceratosebacina longispora

Ceratosphaeria cf subferruginea

Ceratosphaeria lampadophora

Ceratosphaeria rhenana

Ceratostomella rostrata

Cerinomyces crustulinus

Cerioporus leptocephalus

Cerioporus mollis

Ceriporia excelsa

Ceriporia reticulata

Resupinate
Resupinate
Pileate

Resupinate

Resupinate

Resupinate

Resupinate

Ramarioid

Ramarioid

Ramarioid

Discomycetoid

Discomycetoid

Discomycetoid

Discomycetoid

Stromatoid

Stromatoid

Discomycetoid

Pyrenomycetoid

Pyrenomycetoid

Pyrenomycetoid

Pyrenomycetoid

Pyrenomycetoid

Resupinate

Resupinate

Resupinate

Resupinate

Resupinate

Pyrenomycetoid

Pyrenomycetoid

Pyrenomycetoid

Pyrenomycetoid

Resupinate

Pileate

Pileate

Resupinate

Resupinate

48

$1.00 \quad$ Yes

12

3

4

12

31

$11.712 .56 \quad$ No

$42.41 \quad 2.00 \quad$ No

$\begin{array}{lll}43.30 & 1.29 & \text { No }\end{array}$

$\begin{array}{lll}56.00 & 2.08 \quad \text { No }\end{array}$

$18.04 \quad 4.29 \quad$ No

$11.49 \quad 4.33 \quad$ No

$\begin{array}{lll}70.51 & 2.62 \quad \text { No }\end{array}$

$101.02 \quad 3.00 \quad$ No

$113.10 \quad 2.25 \quad$ No

$\begin{array}{ll}11.35 & 2.94 \quad \text { No }\end{array}$

$120.29 \quad 4.46 \quad$ No

$5.54 \quad 4.08$ No

$134.77 \quad 2.24 \quad$ No

$62.54 \quad 1.86 \quad$ No

$62.54 \quad 1.86 \quad$ No

$14.14 \quad 5.33 \quad$ No

$1256.64 \quad 1.60 \quad$ No

337.57

$2.26 \mathrm{No}$

$\begin{array}{lll}795.22 & 2.40 \quad \text { No }\end{array}$

$\begin{array}{lll}795.22 & 2.40 \quad \text { No }\end{array}$

$\begin{array}{lll}452.39 & 2.67 & \text { No }\end{array}$

$28.30 \quad 1.21 \quad$ No

19.30

1.18 No

$\begin{array}{ll}18.89 & 2.11 \quad \text { No }\end{array}$

$87.96 \quad 1.75 \quad$ No

$314.16 \quad 6.25 \quad$ No

$551.35 \quad 3.25 \quad$ No

$692.72 \quad 11.90 \quad$ No

$\begin{array}{lll}463.29 & 3.55 \quad \text { No }\end{array}$

$\begin{array}{lll}12.63 & 3.00 \quad \text { No }\end{array}$

$\begin{array}{lll}82.96 & 3.08 \quad \text { No }\end{array}$

74.32

$2.30 \quad$ No

105.83

3.14

No

16.90

$1.89 \quad$ No

53.01

2.50

No $\begin{array}{llll}7 & 6 & - & 13\end{array}$

1

3

1

17

2

11

12

1

2

5

1

4

2

2

12

1

20

1

10

4

24

18

9

11

1

1

3

30

5

10

2

7

3 
Ceriporia viridans

Ceriporiopsis resinascens

Cerrena unicolor

Chaetoderma luna

Chaetosphaeria cf cupulifera

Chaetosphaeria myriocarpa

Chaetosphaeria sp1.

Chaetosphaeria sp2.

Chaetosphaeria vermicularioides

Cheimonophyllum candidissimum

Chlorencoelia versiformis

Chlorociboria aeruginascens

Chlorociboria aeruginosa

Chrysomphalina chrysophylla

Ciliolarina aff pinicola

Ciliolarina cf laetifica

Ciliolarina concortica

Ciliolarina neglecta

Ciliolarina sp1.

Cinereomyces lindbladii

Cistella cf geelmyedenii

Cistella cf improvisa

Cistella cf microspora

Cistella sp1.

Cistella sp2.

Cistella sp3.

Cistella sp4.

Cistella sp5.

Cistella sp6.

Cistella sp8.

Claussenomyces atrovirens

Clavulicium delectabile

Colacogloea peniophorae

Conferticium ochraceum

Conferticium ravum

Coniochaeta subcorticalis
Resupinate

12.57

Resupinate

Pileate

Resupinate

Pyrenomycetoid

Pyrenomycetoid

Pyrenomycetoid

Pyrenomycetoid

Pyrenomycetoid

Agaricoid

Discomycetoid

Discomycetoid

Discomycetoid

Agaricoid

Discomycetoid

Discomycetoid

Discomycetoid

Discomycetoid

Discomycetoid

Resupinate

Discomycetoid

Discomycetoid

Discomycetoid

Discomycetoid

Discomycetoid

Discomycetoid

Discomycetoid

Discomycetoid

Discomycetoid

Discomycetoid

Discomycetoid

Resupinate

Resupinate

Resupinate

Resupinate

Pyrenomycetoid
92.21

$\begin{array}{lll}31.32 & 2.27 \quad \text { No }\end{array}$

30.62

1.68 No

198.80

$2.78 \quad$ No

389.66

5.44 No

29.45

$2.40 \quad$ No

268.61

12.67 No

191.69

3.07 No

41.72

$3.40 \quad$ No

107.99

1.10 No

91.89

4.33 No

13.83

$3.29 \quad$ No

81.29

3.83 No

249.46

$1.91 \quad$ No

125.66

$2.50 \quad$ No

23.06

$2.58 \quad$ No

14.89

$2.76 \quad$ No

9.45

2.94 No

53.82

3.48

No

16.96

$2.70 \quad$ No

17.01

3.16 No

11.78

3.22 No

$\begin{array}{lll}8.42 & 2.00 \quad \text { No }\end{array}$

25.98

3.57

No

$2.94 \quad$ No

15.71

$2.50 \quad$ No

11.35

2.94

5.97

3.46 No

26.70

4.25 No

57.92

4.72 No

283.73

4.71

No

307.88

$1.14 \quad$ Yes

94.25

1.88 No

1.75 No

$1.53 \quad$ Yes

358.97
3

5

1

6

11

1 


\begin{tabular}{|c|c|c|c|c|c|c|c|c|}
\hline Coniophora arida & Resupinate & 461.81 & 1.71 & No & - & 5 & 3 & 5 \\
\hline Coniophora olivacea & Resupinate & 196.35 & 2.00 & No & 8 & 15 & 11 & 9 \\
\hline Coniophora puteana & Resupinate & 348.42 & 1.62 & No & - & 4 & 2 & 4 \\
\hline Coronicium alboglaucum & Resupinate & 41.58 & 2.55 & No & - & - & - & 1 \\
\hline Coronophora sp nov & Pyrenomycetoid & 31.10 & 4.95 & No & - & - & - & 2 \\
\hline Corticium boreoroseum & Resupinate & 181.62 & 1.85 & No & - & 1 & - & - \\
\hline Corticium polygonioides & Resupinate & 142.35 & 1.45 & No & - & 1 & - & 5 \\
\hline Corticium roseum & Resupinate & 1649.34 & 2.10 & No & 1 & - & - & 6 \\
\hline Crepidotus calolepis & Agaricoid & 220.72 & 1.48 & No & - & - & - & 5 \\
\hline Crepidotus cesatii & Agaricoid & 248.87 & 1.15 & Yes & - & 5 & - & - \\
\hline Crepidotus pallidus & Discomycetoid & 123.26 & 1.72 & Yes & 8 & - & - & 8 \\
\hline Crepidotus subverrucisporus & Agaricoid & 227.21 & 1.52 & Yes & - & 1 & - & - \\
\hline Crocicreas sp1. & Discomycetoid & 5.77 & 4.25 & No & - & - & - & 1 \\
\hline Crustoderma corneum & Resupinate & 177.21 & 2.11 & No & - & - & 1 & - \\
\hline Crustoderma dryinum & Resupinate & 56.55 & 2.67 & No & - & 1 & - & - \\
\hline Crustoderma efibulatum & Resupinate & 21.83 & 4.05 & No & - & - & 1 & - \\
\hline Cryptodiscus foveolaris & Discomycetoid & 44.55 & 2.73 & No & 1 & - & - & - \\
\hline Cryptodiscus pallidus & Discomycetoid & 198.61 & 3.29 & No & - & - & - & 1 \\
\hline Cryptodiscus pini & Discomycetoid & 26.46 & 6.29 & No & - & - & 10 & - \\
\hline Cudonia confusa & Agaricoid & 159.04 & 17.78 & No & - & 1 & - & - \\
\hline Cyathicula sp1. & Discomycetoid & 381.70 & 5.33 & No & - & - & 1 & 1 \\
\hline Cyathicula sp2. & Discomycetoid & 125.29 & 5.35 & No & - & - & - & 1 \\
\hline Cylindrobasidium evolvens & Resupinate & 181.62 & 1.85 & No & 4 & - & - & 4 \\
\hline Cystoderma jasonis & Agaricoid & 74.55 & 1.80 & No & - & - & 2 & - \\
\hline Dacrymyces adpressus & Discomycetoid & 383.02 & 2.57 & No & - & - & 1 & - \\
\hline Dacrymyces lacrymalis & Discomycetoid & 230.37 & 2.74 & No & 1 & 2 & - & 5 \\
\hline Dacrymyces macnabbii & Discomycetoid & 89.00 & 2.64 & No & - & 7 & 8 & 1 \\
\hline Dacrymyces microsporus & Discomycetoid & 89.00 & 2.64 & No & - & 10 & 3 & 3 \\
\hline Dacrymyces minor & Discomycetoid & 166.69 & 2.76 & No & 4 & 6 & - & 6 \\
\hline Dacrymyces minutus & Discomycetoid & 121.49 & 2.93 & No & - & 7 & 2 & - \\
\hline Dacrymyces ovisporus & Discomycetoid & 1491.03 & 1.33 & No & - & 1 & 1 & - \\
\hline Dacrymyces sp1. & Discomycetoid & 954.26 & 1.67 & No & - & - & 1 & - \\
\hline Dacrymyces sp2. & Discomycetoid & 110.84 & 1.90 & No & - & 1 & - & - \\
\hline Dacrymyces stillatus & Discomycetoid & 368.25 & 2.82 & No & - & 17 & 17 & - \\
\hline Dacrymyces tortus & Discomycetoid & 138.06 & 3.33 & No & - & 8 & 16 & - \\
\hline Dacryobolus karstenii & Resupinate & 7.51 & 3.89 & No & - & 2 & 3 & - \\
\hline
\end{tabular}




\begin{tabular}{|c|c|c|c|c|c|c|c|c|}
\hline Dacryobolus sudans & Resupinate & 9.72 & 3.67 & No & - & 3 & 1 & 1 \\
\hline Daldinia concentrica & Stromatoid & 753.98 & 1.88 & No & 1 & - & - & - \\
\hline Dialonectria cf episphaeria & Pyrenomycetoid & 270.59 & 2.38 & Yes & 5 & - & - & 1 \\
\hline Diatrype stigma & Stromatoid & 31.42 & 5.00 & No & 1 & - & - & - \\
\hline Diatrypella sp1. & Stromatoid & 5.32 & 5.09 & No & 1 & - & - & - \\
\hline Dichostereum boreale & Resupinate & 57.98 & 1.40 & Yes & - & 1 & - & - \\
\hline Ditiola peziziformis & Discomycetoid & 1813.09 & 3.17 & No & - & - & 1 & - \\
\hline Durella melanochlora & Discomycetoid & 239.23 & 2.84 & No & 6 & - & - & 7 \\
\hline Echinosphaeria canescens & Pyrenomycetoid & 556.65 & 7.78 & No & 2 & - & - & 1 \\
\hline Echinosphaeria cincinnata & Pyrenomycetoid & 261.34 & 2.00 & No & 2 & 1 & 1 & - \\
\hline Elmerina caryae & Resupinate & 27.24 & 2.22 & No & 4 & - & - & - \\
\hline Endoxyla macrostoma & Pyrenomycetoid & 67.73 & 3.93 & No & - & 1 & - & - \\
\hline Endoxyla parallela & Stromatoid & 84.55 & 4.41 & No & 1 & 2 & 3 & 5 \\
\hline Endoxyla rostrata & Pyrenomycetoid & 12.63 & 3.00 & No & 4 & - & - & - \\
\hline Entoloma depluens & Agaricoid & 402.50 & 1.34 & No & 2 & - & - & 1 \\
\hline Eutypa flavovirens & Stromatoid & 27.83 & 3.11 & No & 5 & - & - & 2 \\
\hline Exidia glandulosa & Discomycetoid & 163.36 & 3.25 & No & 3 & - & - & 3 \\
\hline Exidia repansa & Discomycetoid & 91.89 & 4.33 & No & 3 & - & - & - \\
\hline Exidia saccharina & Discomycetoid & 135.30 & 3.27 & No & - & - & 1 & - \\
\hline Exidiopsis calcea & Resupinate & 376.52 & 2.52 & No & - & 1 & - & - \\
\hline Exidiopsis effusa & Resupinate & 218.68 & 3.06 & No & - & - & - & 1 \\
\hline Flagelloscypha sp1. & Discomycetoid & 137.44 & 1.40 & No & - & - & - & 1 \\
\hline Flammulaster limulatus & Agaricoid & 113.49 & 1.88 & No & 4 & - & - & 8 \\
\hline Flaviporus citrinellus & Resupinate & 13.09 & 1.37 & No & - & 1 & 1 & 1 \\
\hline Fomes fomentarius & Pileate & 356.37 & 2.73 & No & 40 & - & - & 5 \\
\hline Fomitopsis betulina & Pileate & 9.72 & 3.67 & No & 2 & - & - & - \\
\hline Fomitopsis pinicola & Pileate & 94.25 & 1.88 & No & 22 & 33 & 9 & 9 \\
\hline Fomitopsis rosea & Pileate & 27.34 & 2.37 & No & - & 3 & - & - \\
\hline Galerina hypnorum & Agaricoid & 194.83 & 1.71 & Yes & - & 2 & - & - \\
\hline Galerina marginata & Agaricoid & 246.69 & 1.65 & Yes & - & 1 & 1 & 5 \\
\hline Galerina mniophila & Agaricoid & 285.64 & 1.91 & Yes & - & 1 & 2 & - \\
\hline Galerina pumila & Agaricoid & 332.22 & 1.96 & No & - & - & 1 & - \\
\hline Galerina stylifera & Agaricoid & 111.33 & 1.56 & No & - & 1 & 2 & 2 \\
\hline Galzinia incrustans coll & Resupinate & 15.71 & 2.50 & No & 2 & 1 & 2 & 5 \\
\hline Ganoderma applanatum & Pileate & 209.35 & 1.48 & Yes & - & - & - & 1 \\
\hline Gelatoporia dichrous & Pileate & 4.67 & 3.91 & No & 1 & - & - & - \\
\hline
\end{tabular}


Globulicium hiemale

Gloeocystidiellum convolvens

Gloeocystidiellum leucoxanthum

Gloeocystidiellum luridum

Gloeocystidiellum porosum

Gloeodontia subasperispora

Gloeophyllum sepiarium

Gloeoporus pannocinctus

Gloeoporus taxicola

Gloiothele citrina

Glonium nitidum

Godronia urceolus

Gorgoniceps aridula

Gorgoniceps hypothallosa

Gymnopilus penetrans

Gymnopilus picreus

Gymnopus androsaceus

Gymnopus confluens

Gymnopus dryophilus

Gyromitra infula

Hamatocanthoscypha laricionis

Hamatocanthoscypha sp nov

Hamatocanthoscypha sp1.

Hamatocanthoscypha sp2.

Hamatocanthoscypha sp3.

Hamatocanthoscypha straminella

Helicobasidium sp1.

Helminthosphaeria aff carpathica

Helminthosphaeria aff odontiae

Helminthosphaeria aff pilifera

Helminthosphaeria cf gibberosa

Helminthosphaeria ludens

Helminthosphaeria sp1.

Helminthosphaeriaceae sp nov.

Helvella macropus

Hemimycena sp1.
Resupinate

Resupinate

Resupinate

Resupinate

Resupinate

Resupinate

Pileate

Resupinate

Resupinate

Resupinate

Pyrenomycetoid

Discomycetoid

Discomycetoid

Discomycetoid

Agaricoid

Agaricoid

Agaricoid

Agaricoid

Agaricoid

Agaricoid

Discomycetoid

Discomycetoid

Discomycetoid

Discomycetoid

Discomycetoid

Discomycetoid

Resupinate

Pyrenomycetoid

Pyrenomycetoid

Pyrenomycetoid

Pyrenomycetoid

Pyrenomycetoid

Pyrenomycetoid

Pyrenomycetoid

Agaricoid

Agaricoid
$1194.49 \quad 1.00 \quad$ No

$33.58 \quad 1.58 \quad$ Yes

$\begin{array}{lll}356.37 & 2.73 \quad \text { No }\end{array}$

$\begin{array}{lll}168.35 & 2.00 \quad \text { No }\end{array}$

35.34

1.67 Yes

15.90

$1.78 \quad$ Yes

71.58

$2.78 \quad$ No

1.86

$4.63 \quad$ No

6.61

$2.76 \quad$ No

71.57

$1.00 \quad$ No

$68.72 \quad 5.60 \quad$ No

$110.45 \quad 41.67 \quad$ No

$308.15 \quad 34.44 \quad$ No

$190.85 \quad 9.00 \quad$ No

$141.76 \quad 1.68 \quad$ Yes

$268.61 \quad 1.58 \quad$ Yes

$109.94 \quad 1.82 \quad$ No

$\begin{array}{lll}69.75 & 2.07 \quad \text { No }\end{array}$

45.63

$1.69 \quad$ No

$\begin{array}{lll}1095.85 & 2.48 \quad \text { No }\end{array}$

$\begin{array}{lll}13.15 & 3.73 \quad \text { No }\end{array}$

38.78

$3.16 \quad$ No

15.27

$3.33 \quad$ No

26.23

3.14

10.43

3.93

37.32

3.44

500.30

1.86

285.10

$2.18 \quad$ No

176.71

$1.80 \quad$ No

238.12

$2.10 \quad$ No

464.56

$2.15 \quad$ No

$1105.84 \quad 2.75 \quad$ No

320.74

$2.45 \quad$ No

$1269.11 \quad 2.29 \quad$ Yes

1991.5

2.19

Yes

268.61
$21 \quad 16$

37

6

5

2

3

2

1

8

3

14

2

1

1

6

35

7

6

1

2

5

1

1

1

5

1

6

1

2

2

1

4

8

1

8 
Henningsomyces candidus

Henningsomyces pienikarva

Hericium cirrhatum

Hericium coralloides

Hilberina aff moseri

Hilberina aff munkii

Hilberina cf caudata

Humaria hemisphaerica

Hyalopeziza millepunctata

Hyaloscypha albohyalina

Hyaloscypha aureliella

Hyaloscypha diabolica

Hyaloscypha epiporia

Hyaloscypha fuckelii

Hyaloscypha intacta

Hyaloscypha latispora

Hyaloscypha leuconica

Hyaloscypha quercicola

Hyaloscypha sp1. nov.

Hyaloscypha spiralis

Hyaloscypha vitreola

Hymenochaete fuliginosa

Hymenochaetopsis tabacina

Hymenoscyphus sp2.

Hymenoscyphus sp3.

Hymenoscyphus vikgultorum

Hyphoderma cremeoalbum

Hyphoderma definitum

Hyphoderma incrustatum

Hyphoderma obtusiforme

Hyphoderma occidentale

Hyphoderma roseocremeum

Hyphoderma setigerum

Hyphoderma sibiricum

Hyphodiscus hemiamyloideus

Hyphodiscus hymeniophilus
Discomycetoid

81.91

1.14 No

14

81.91

$1.14 \quad$ No

Discomycetoid

28.27

Pileate

35.26

$1.33 \quad$ No

Ramarioid

Pyrenomycetoid

692.72

$1.31 \quad$ Yes

Pyrenomycetoid

326.73

$11.90 \quad$ No

Pyrenomycetoid

596.90

$6.50 \quad$ No

Discomycetoid

Discomycetoid

Discomycetoid

Discomycetoid

Discomycetoid

Discomycetoid

Discomycetoid

Discomycetoid

Discomycetoid

Discomycetoid

Discomycetoid

Discomycetoid

Discomycetoid

Discomycetoid

Resupinate

Pileate

Discomycetoid

Discomycetoid

Discomycetoid

Resupinate

Resupinate

Resupinate

Resupinate

Resupinate

Resupinate

Resupinate

Resupinate

Discomycetoid

Discomycetoid
25.22

8.84

$2596.72 \quad 2.17 \quad$ Yes

19.14

3.55

No

3.36 No

$\begin{array}{lll}40.50 & 3.30 \quad \text { No }\end{array}$

19.16

$3.05 \quad$ No

28.04

$2.93 \quad$ No

38.04

$3.10 \quad$ No

105.83

3.14 No

83.71

2.19 No

41.39

$3.81 \quad$ No

41.72

3.40

14.77

2.35

113.05

$3.36 \quad$ No

113.05

3.36 No

18.06

$2.88 \quad$ No

$2.30 \quad$ No

4.14 No

427.65

$3.27 \quad$ No

123.70

$5.83 \quad$ No

311.61

$2.09 \quad$ No

103.70

$3.85 \quad$ No

198.80

261.34

$2.00 \quad$ No

230.37

$2.74 \quad$ No

101.02

$3.00 \quad$ No

93.88

$2.27 \quad$ No

13

$1.78 \quad$ No

$1.83 \quad$ No

8

$3.33 \quad \mathrm{No}$
$2.78 \quad$ No
15

2

1

1

1

2

3

11

5

12

92

1

3

38

24

1

22

1

1

10

28

3

2

1

1

1

2

9

6

1

4

1

29

18 
Hyphodontia abieticola

Hyphodontia alutaria

Hyphodontia barba-jovis

Hyphodontia curvispora

Hyphodontia efibulata

Hyphodontia pallidula

Hyphodontia subalutacea

Hypholoma fasciculare

Hypholoma polytrichi

Hypochnicium albostramineum

Hypochnicium bombycinum

Hypochnicium polonese

Hypochnicium punctulatum

Hypochnicium subrigescens

Hypochnicium wakefieldiae

Hypomyces rosellus

Hypomyces semitranslucens

Hypoxylon fuscum

Hypoxylon rubiginosum

Hysterium pulicare

Hysterographium fraxini

Immersiella caudata

Inonotus obliquus

Irpex litschaueri

Ischnoderma benzoinum

Jaapia ochroleuca

Junghuhnia collabens

Junghuhnia luteoalba

Kirschsteiniothelia cf atra

Kuehneromyces lignicola

Kuehneromyces mutabilis

Kurtia argillacea

Lachnella sp1.

Lachnum corticale

Lachnum pudibundum

Lachnum sp1.
Resupinate

55.32

Resupinate

39.40

Resupinate

62.83

Resupinate

5.52

Resupinate

99.30

Resupinate

15.90

Resupinate

16.84

Agaricoid

Agaricoid

Resupinate

Resupinate

Resupinate

Resupinate

Resupinate

Resupinate

Resupinate

Resupinate

Stromatoid

Stromatoid

Pyrenomycetoid

Pyrenomycetoid

Pyrenomycetoid

Resupinate

Resupinate

Pileate

Resupinate

Resupinate

Resupinate

Pyrenomycetoid

Agaricoid

Agaricoid

Resupinate

Discomycetoid

Discomycetoid

Discomycetoid

Discomycetoid

99.30

127.23

322.06

404.09

119.28

106.32

149.31

188.26

437.37

447.97

215.98

17.32

14.43

265.07

6.42

11.71

84.82

84.82

119.28

63.54

231.94

25.13

25.24
$1.33 \quad$ Yes

1.50

No

1.67

1.26 Yes

$1.00 \quad$ Yes

$1.26 \quad$ Yes

6.11 Yes

$372.13 \quad 4.42 \quad$ Yes

2.08

2.20

No

$1256.64 \quad 3.13 \quad$ No

$5367.71 \quad 2.78 \quad$ No

$874.74 \quad 12.22 \quad$ No

$261.54 \quad 1.54 \quad$ No

2.38

3.43

No

$2.70 \quad$ Yes

2.19

2.56

No

3.16 No

1.69 No

1.69

No

1.67

No

$2.47 \quad$ No

5.60

No

4.00

No

$4.33 \quad$ No

12

3

12
9

2

5

1

2

18

35

1

1

4

3

1

11

3

6

1

4

1

9

35

8

14

5

1

4

6

1

20

2

3

1

31

1

30 
Lachnum sp2.

Lachnum virgineum

Laetinaeria aff uvidula

Lasiosphaeria hirsuta/tuberculosa complex

Lasiosphaeria ovina

Lasiosphaeria pyramidata

Laxitextum bicolor

Lentaria afflata

Lentinellus castoreus

Lentinellus flabelliformis

Lentinellus micheneri

Lentinellus ursinus

Lentinus substrictus

Lentomitella cirrhosa

Lentomitella crinigera

Lentomitella tomentosa

Lenzites betulina

Leptodontidium trabinellum

Leptoporus mollis

Leptosporomyces galzinii

Leptosporomyces septentrionalis

Leucogyrophana romellii

Leucogyrophana sororia

Leucoscypha leucotricha

Lophiostoma cf quadrinucleatum

Lophiostoma compressum

Lophiostoma curtum

Lophiostoma sp1.

Lophiotrema boreale

Lophium mytilinum

Megacollybia platyphylla

Melanomma cf fuscidulum

Melanomma pulvis-pyrius

Melanomma subdispersum

Melanopsamma pomiformis
Discomycetoid

23.81

3.79

No

Discomycetoid

24.19

$4.86 \quad$ No

Discomycetoid

434.92

1.94

$2156.90 \quad 10.00 \quad$ Yes

13

17

Pyrenomycetoid

Pyrenomycetoid

565.49

$11.25 \quad$ No

628.32

$12.50 \quad$ No

Pyrenomycetoid

Pileate

Ramarioid

23.32

$1.90 \quad$ Yes

60.13

$1.79 \quad$ No

Agaricoid

28.27

1.33 Yes

Agaricoid

60.75

1.47 Yes

Agaricoid

60.75

$1.47 \quad$ Yes

Agaricoid

28.27

1.33 Yes

Pileate

Pyrenomycetoid

17.91

$2.85 \quad$ No

82.83

$2.00 \quad$ Yes

Pyrenomycetoid

285.10

$2.18 \quad$ Yes

Pyrenomycetoid

481.15

$2.23 \quad$ No

Pileate

Discomycetoid

27.00

$2.20 \quad$ No

115.68

2.68 No

Pileate

20.72

2.48

Resupinate

8.42

2.00

Resupinate

15.03

3.57

41.48

1.54

Resupinate

Resupinate

Discomycetoid

Pyrenomycetoid

Pyrenomycetoid

Pyrenomycetoid

Pyrenomycetoid

Pyrenomycetoid

Pyrenomycetoid

Agaricoid

Pyrenomycetoid

Pyrenomycetoid

Pyrenomycetoid

Pyrenomycetoid

1.55

$25.24 \quad 1.55 \quad$ No

$5366.72 \quad 2.24 \quad$ Yes

$\begin{array}{lll}1325.60 & 2.95 \quad \text { No }\end{array}$

$\begin{array}{llll}1615.37 & 2.64 \quad \text { No } & 2\end{array}$

$\begin{array}{llll}608.97 & 2.70 \quad \text { No } & 9\end{array}$

345.25

$4.92 \quad$ No

169.63

$3.64 \quad$ No

636.17

71.11 No

350.90

1.1

226.19

4.50

254.4

3.56

994.02

3.00

497.75 
Melanospora caprina

Menispora cf glauca/caesia

Merismodes anomala

Merulius tremellosus

Metulodontia nivea

Mollisia sp1.

Mollisia sp2.

Mollisia sp3.

Mollisia sp4.

Mucronella calva

Mycena algeriensis

Mycena amicta

Mycena epipterygia

Mycena galericulata

Mycena galopus

Mycena haematopus

Mycena laevigata

Mycena leptocephala

Mycena metata/filopes

Mycena rubromarginata

Mycena sanguinolenta

Mycena silvae-nigrae

Mycena stipata

Mycena tintinnabulum

Mycena viridimarginata

Mycoacia aurea

Mycoacia fuscoatra

Mytilinidion mytilinellum

Myxarium sp1.

Natantiella ligneola

Nectria peziza

Nemania atropurpurea

Nemania dark sp.

Nemania genea

Nemania serpens

Neobulgaria lilacina
Pyrenomycetoi

Pyrenomycetoid

$2393.01 \quad 1.56 \quad$ No

Discomycetoid

$413.51 \quad 5.78 \quad$ No

$\begin{array}{lll}1005.31 & 2.50 \quad \text { No }\end{array}$

Pileate

5.22

$3.40 \quad$ No

Resupinate

37.33

$1.38 \quad$ No

Discomycetoid

33.80

3.78 No

Discomycetoid

316.42

2.18 No

129.27

3.53

18.85

Discomycetoid

Ramarioid

35.34

3.00

1.67 No

220.72

1.48

150.62

1.79

298.65

1.38 No

451.59

1.42

311.02

1.83 No

220.72

$1.48 \quad$ No

Agaricoid

Agaricoid

Agaricoid

Agaricoid

Agaricoid

Agaricoid

Agaricoid

Agaricoid

Agaricoid

Agaricoid

Resupinate

Resupinate

Pyrenomycetoid

Discomycetoid

Pyrenomycetoid

84.82

$1.69 \quad$ No

186.53

1.90

186.53

$1.90 \quad$ No

331.83

1.54 No

184.00

1.62 No

552.92

1.38

306.80

1.60

No

22.09

1.80

346.36

$1.29 \quad$ No

10.82

$2.57 \quad$ No

21.87

2.44

182.80

5.43

166.90

1.70

124.25

1.70

Pyrenomycetoid

296.98

$3.00 \quad$ No

$2.27 \quad$ Yes

Stromatoid

190.00

2.19

313.87

2.16

423.77

2.63

383.50

2.63

Stromatoid

Stromatoid

2.00

141.86

Discomycetoid

No 10

18

$2.35 \quad$ Yes 11

2

2

4 
Neodasyscypha cerina

Niesslia sp.

Oligoporus alni

Orbilia auricolor

Orbilia delicatula

Orbilia sp1.

Orbilia sp2.

Orbilia sp3.

Orbilia sp4.

Orbilia sp5.

Orbilia sp6.

Orbilia sp7.

Orbilia sp8.

Otidea tuomikoskii

Oxyporus corticola

Panellus mitis

Panellus serotinus

Panus conchatus

Patinellaria sanguinea

Paullicorticium pearsonii

Paullicorticium seorsum

Peniophora incarnata

Peniophora laurentii

Peniophora nuda

Peniophora pithya

Peniophora polygonia

Peniophora violaceolivida

Peniophorella guttuliferum

Peniophorella pallida

Peniophorella praetermissa

Peniophorella pubera

Perenniporia subacida

Peziza cf arvernensis

Pezizella sp1.

Pezizella sp2.

Phaeohelotium sp1.
Discomycetoid

29.45

Pyrenomycetoid

7.03

Pileate

5.88

Discomycetoid

4.64

Discomycetoid

1.78

Discomycetoid

2.54

Discomycetoid

6.28

Discomycetoid

17.49

Discomycetoid

3.80

Discomycetoid

8.03

Discomycetoid

1.31

Discomycetoid

38.84

Discomycetoid

3.50

Agaricoid

Resupinate

Agaricoid

Agaricoid

Agaricoid

Discomycetoid

Resupinate

Resupinate

Resupinate

Resupinate

Resupinate

Resupinate

Resupinate

Resupinate

Resupinate

Resupinate

Resupinate

Resupinate

Resupinate

Discomycetoid

Discomycetoid

Discomycetoid

Discomycetoid

56.45

5.83

8.39

44.18

70.51

34.36

55.22

53.46

30.68

91.25

50.49

68.44

56.55

54.44

75.63

24.82

44.18
2.40

No

5.89 No

$4.33 \quad$ No

$14.00 \quad$ No

$2.27 \quad$ Yes $\quad 30$

7.67 No 16

$8.00 \quad$ No

2.09 No

3.64 No

5.92 No

4.86 No

$7.21 \quad$ No

$6.11 \quad$ No

303.95

1.79 No

1.42 No

$3.80 \quad$ No

$3.17 \quad$ No

$2.08 \quad$ No

2.62 No

$2.80 \quad$ No

$1.33 \quad$ No

$\begin{array}{lll}113.10 & 2.25 \quad \text { No }\end{array}$

$\begin{array}{lll}174.95 & 2.44 \quad \text { No }\end{array}$

$3.27 \quad$ No

$2.50 \quad$ No

$3.38 \quad$ No

3.09 No

2.54 No

2.67 No

177.21

$2.11 \quad$ No

120.58

2.00

No

1.26

1287.92

1.77

3.57

3.95

3.60

3

4

7

1

(1)

1

$\begin{array}{cccc}1 & 1 & 12 & 30 \\ - & - & 1 & 4 \\ 2 & & & \end{array}$

5

$$
2
$$

10


Phaeohelotium sp2.

Phaeohelotium sp3.

Phanerochaete calotricha

Phanerochaete laevis

Phanerochaete sordida

Phanerochaete velutina

Phellinus ferrugineofuscus

Phellinus igniarius coll

Phellinus laevigatus

Phellinus lundellii

Phellinus nigrolimitatus

Phellinus tremulae

Phellinus viticola

Phialocephala piceae

Phlebia centrifuga

Phlebia femsjoeensis

Phlebia lilascens coll

Phlebia livida

Phlebia radiata

Phlebia rufa

Phlebia segregata

Phlebia serialis

Phlebia subserialis

Phlebia subulata

Phlebia tuberculata

Phlebiella christiansenii

Phlebiopsis gigantea

Phloeomana clavata

Phloeomana hiemalis

Phloeomana speirea

Pholiota flammans

Pholiota scamba

Pholiota squarrosa

Pholiota tuberculosa

Piloderma bicolor

Piloderma byssinum
Discomycetoid

Discomycetoid

Resupinate

Resupinate

Resupinate

Resupinate

Resupinate

Pileate

Resupinate

Pileate

Pileate

Pileate

Pileate

Discomycetoid

Resupinate

Resupinate

Resupinate

Resupinate

Resupinate

Resupinate

Resupinate

Resupinate

Resupinate

Resupinate

Resupinate

Pileate

Resupinate

Agaricoid

Agaricoid

Agaricoid

Agaricoid

Agaricoid

Agaricoid

Agaricoid

Resupinate

Resupinate
15.59

14.46

15.90

34.15

35.64

35.64

6.94

127.42

2.89

2.68

No

1.78 No

$2.09 \quad$ No

2.18 No

$2.18 \quad$ No

$2.90 \quad$ No

1.15 No

46.03

$1.31 \quad$ No

82.87

1.24 No

21.87

$2.44 \quad$ No

65.56

1.35 No

17.30

$3.78 \quad$ No

$4.22 \quad$ No

44.55

$2.73 \quad$ No

17.89

$2.00 \quad$ No

16.90

1.89 No

21.87

$2.44 \quad$ No

10.82

$2.57 \quad$ No

21.87

$2.44 \quad$ No

25.84

$2.89 \quad$ No

11.76

$3.33 \quad$ No

25.84

$2.89 \quad$ No

28.21

$1.73 \quad$ No

47.71

$2.25 \quad$ No

92.21

1.53 Yes

60.14

2.23

212.06

1.25

No

161.05

1.38

161.99

1.65

22.09

1.80

184.00

1.62

99.30

1.65

141.76

1.68

15.95

$\begin{array}{lll}1.30 \quad \text { No } & 18\end{array}$

52.46

1.27

No

13

15

1

15

17

17

12 


\begin{tabular}{|c|c|c|c|c|c|c|c|c|}
\hline Piloderma olivaceum & Resupinate & 15.95 & 1.30 & No & 1 & 2 & 4 & 1 \\
\hline Piloderma sp1. & Resupinate & 29.81 & 1.27 & No & 1 & - & - & 1 \\
\hline Piloderma sphaerosporum & Resupinate & 23.12 & 1.21 & No & 1 & 1 & 3 & 4 \\
\hline Pisorisporium sp. & Pyrenomycetoid & 561.24 & 11.59 & No & 4 & - & - & 10 \\
\hline Platystomum obtectum & Pyrenomycetoid & 1842.94 & 2.74 & No & - & - & 3 & - \\
\hline Pleurotus pulmonarius & Agaricoid & 104.92 & 2.53 & No & - & - & - & 1 \\
\hline Pluteus cervinus & Agaricoid & 158.03 & 1.39 & No & 15 & - & - & 3 \\
\hline Pluteus podospileus & Agaricoid & 140.71 & 1.24 & No & 2 & - & - & - \\
\hline Pluteus semibulbosus & Agaricoid & 160.37 & 1.23 & No & 1 & - & - & 1 \\
\hline Polydesmia pruinosa & Discomycetoid & 278.33 & 3.89 & No & 3 & - & - & 8 \\
\hline Postia caesia coll. & Pileate & 9.01 & 3.40 & No & - & 7 & - & - \\
\hline Postia fragilis & Pileate & 10.28 & 3.52 & No & 1 & 1 & 3 & - \\
\hline Postia guttulata & Pileate & 19.00 & 1.75 & No & - & 1 & 1 & - \\
\hline Postia leucomallella & Pileate & 10.28 & 3.52 & No & - & 3 & 6 & - \\
\hline Postia ptychogaster & Resupinate & 19.52 & 1.91 & No & - & 1 & 1 & - \\
\hline Postia rennyi & Resupinate & 26.47 & 1.81 & No & - & - & 1 & - \\
\hline Postia sericeomollis & Resupinate & 14.37 & 1.98 & No & - & 1 & 3 & - \\
\hline Postia tephroleuca & Pileate & 8.39 & 3.17 & No & 1 & 6 & 3 & - \\
\hline Postia undosa & Pileate & 9.62 & 3.29 & No & - & - & - & 1 \\
\hline Propolis farinosa & Discomycetoid & 607.90 & 3.58 & No & 13 & - & - & 21 \\
\hline Propolis sp1. & Discomycetoid & 2120.58 & 2.70 & No & - & 6 & 1 & - \\
\hline Protodontia piceicola & Resupinate & 56.55 & 1.13 & No & - & 1 & - & - \\
\hline Protodontia subgelatinosa & Resupinate & 115.18 & 1.37 & No & 5 & - & - & - \\
\hline Protounguicularia transiens & Discomycetoid & 31.81 & 3.56 & No & 3 & - & - & 4 \\
\hline Pseudocosmospora vilior & Pyrenomycetoid & 270.59 & 2.38 & Yes & 5 & 1 & - & - \\
\hline Pseudographis pinicola & Discomycetoid & 2990.01 & 5.22 & No & - & 1 & 1 & - \\
\hline Pseudohydnum gelatinosum & Pileate & 148.49 & 1.14 & No & - & 2 & - & - \\
\hline Pseudoplectania nigrella & Discomycetoid & 1045.36 & 1.00 & No & 6 & 7 & 13 & 4 \\
\hline Pseudotomentella flavovirens & Resupinate & 215.69 & 1.00 & Yes & - & 1 & - & - \\
\hline $\begin{array}{l}\text { Pseudotomentella } \\
\text { griseopergamacea }\end{array}$ & Resupinate & 526.16 & 1.00 & Yes & 3 & 1 & - & 1 \\
\hline Pseudotomentella humicola & Resupinate & 269.39 & 1.00 & Yes & - & - & - & 1 \\
\hline Pseudotomentella mucidula & Resupinate & 331.34 & 1.00 & Yes & 1 & - & 2 & - \\
\hline Pseudotomentella nigra & Resupinate & 572.56 & 1.00 & Yes & - & - & - & 2 \\
\hline Pseudotomentella tristis & Resupinate & 307.88 & 1.14 & Yes & 1 & - & 2 & 3 \\
\hline Psilocistella cf conincola & Discomycetoid & 38.61 & 2.36 & No & - & - & 1 & - \\
\hline
\end{tabular}


Psilocistella obsoleta

Psilocistella sp tummakarva

Psilocistella sp2.

Psilocistella sp3.

Psilocistella sp4.

Psilocistella sp5.

Psilocistella sp6.

Pycnoporellus fulgens

Radulomyces confluens

Rectipilus fasciculatus

Repetobasidium vile

Resinicium bicolor

Resinicium furfuraceum

Resupinatus poriaeformis

Rhizochaete sulphurina

Rhizochaete violascens

Rhizoctonia fusisporus

Rhizoctonia ochracea

Rhizoctonia pseudocornigerum

Rhodonia placenta

Roridomyces roridus

Schizopora paradoxa

Scopuloides rimosa

Scutellinia scutellata

Scytinostroma galactinum

Scytinostromella heterogenea

Sebacina grisea

Serpula himantioides

Sidera lunata

Simocybe centunculus

Simocybe haustellaris

Sistotrema aff binucleosporum

Sistotrema aff farinaceum

Sistotrema brinkmannii

Sistotrema coroniferum

Sistotrema coronilla
Discomycetoid

3.99

2.60

Discomycetoid

22.51

Discomycetoid

197.29

3.10

3.93

Discomycetoid

7.85

Discomycetoid

11.31

3.64

$4.27 \quad$ No

Discomycetoid

85.53

3.03 No

Discomycetoid

21.99

$3.50 \quad$ No

Pileate

38.17

Resupinate

299.30

$1.80 \quad$ No

$1.00 \quad$ Yes

Discomycetoid

40.64

1.92 No

Resupinate

34.36

Resupinate

44.18

$2.80 \quad$ No

Resupinate

31.18

$2.08 \quad$ No

$1.91 \quad$ No

113.65

$1.00 \quad$ No

29.70

1.82 No

45.63

Resupinate

Resupinate

$1.69 \quad$ No

Resupinate

Resupinate

Resupinate

Agaricoid

Resupinate

Resupinate

Discomycetoid

Resupinate

Resupinate

Resupinate

Resupinate

Resupinate

Agaricoid

Agaricoid

Resupinate

Resupinate

Resupinate

Resupinate

Resupinate
39.27

$6.25 \quad$ No

$307.88 \quad 1.14 \quad$ No

$96.21 \quad 2.86 \quad$ No

$26.51 \quad 2.16 \quad$ No

$\begin{array}{lll}186.07 & 2.21 \quad \text { No }\end{array}$

$\begin{array}{lll}66.36 & 1.48 \quad \text { No }\end{array}$

$\begin{array}{lll}9.62 & 2.29 \quad \text { No }\end{array}$

$1758.11 \quad 1.68 \quad$ Yes

$\begin{array}{lll}23.32 & 1.90 \quad \text { No }\end{array}$

$30.04 \quad 1.42 \quad$ Yes

178.92

2.50

249.46

$1.91 \quad$ Yes

4.31

2.50

No

142.35

1.45 No

201.95

$1.55 \quad$ No

7.59

$2.15 \quad$ No

15.38

1.42 No

14.72

2.02

No

23.86

2.67

No

18.62

2.47

No 
Sistotrema octosporum coll

Sistotrema porulosum

Sistotrema raduloides

Sistotrema resinicystidium

Sistotrema sernanderi

Sistotrema sp nov.

Sistotremastrum suecicum

Sistotremella perpusilla

Skeletocutis amorpha

Skeletocutis biguttulata

Skeletocutis brevispora

Skeletocutis carneogrisea

Skeletocutis kuehneri

Skeletocutis nivea

Skeletocutis

papyracea/subincarnata

Skeletocutis stellae

Sphaerobasidium minutum

Sphaerostilbella berkeleyana

Steccherinum lacerum

Steccherinum ochraceum

Stereum hirsutum

Stereum rugosum

Stereum sanguinolentum

Stereum subtomentosum

Stictis cf mollis

Stictis sp1.

Strossmayeria basitricha

Strossmayeria nigra

Stypella dubia

Stypella vermiformis

Subulicystidium longisporum

Suillosporium cystidiatum

Tapinella panuoides

Tomentella badia

Tomentella botryoides
Resupinate

29.70

Resupinate

20.86

Resupinate

53.01

Resupinate

22.09

Resupinate

35.64

Resupinate

3.85

Resupinate

12.63

Resupinate

Pileate

Resupinate

Resupinate

Pileate

Resupinate

Pileate

Resupinate

15.90

4.78

8.24

5.15

2.86

1.78

1.99

7.43

Resupinate

3.34

37.33

Resupinate

Resupinate

105.83

Resupinate

34.58

Resupinate

14.53

Pileate

Pileate

Pileate

Pileate

Discomycetoid

45.95

186.53

63.62

26.84

649.0

Discomycetoid

77.90

Discomycetoid

Discomycetoid

Resupinate

Resupinate

Resupinate

Resupinate

Agaricoid

Resupinate

Resupinate

414.69

349.44

75.40

55.22

80.18

48.11

785.40

232.28
1.82 No

$1.70 \quad$ No

$2.50 \quad$ No

$1.80 \quad$ No

2.18 No

$1.79 \quad$ No

$3.00 \quad$ No

$1.78 \quad$ No

$2.77 \quad$ No

3.82 No

$2.67 \quad$ No

$3.14 \quad$ No

$4.44 \quad$ No

$6.00 \quad$ No

3.10 No

$4.25 \quad$ No

$1.38 \quad$ No

3.14 Yes

$1.34 \quad$ No

$1.43 \quad$ No

$2.17 \quad$ No

$1.90 \quad$ No

$3.00 \quad$ No

$3.00 \quad$ No

$91.83 \quad$ No

65.22 No

$8.25 \quad$ No

$8.78 \quad$ No

1.33 No

4.91

No

13

$\begin{array}{lll}163.36 & 3.25 \quad \text { No }\end{array}$

$1.43 \quad$ No

1.00

Yes

1.08
$1.50 \quad$ No

4

$\begin{array}{llll}- & 1 & 3 & 8 \\ - & - & 3 & 3 \\ - & - & 2 & 6 \\ 1 & 1 & 2 & 7\end{array}$


Tomentella brevispina

Tomentella bryophila

Tomentella cinerascens

Tomentella coerulea

Tomentella ellisii

Tomentella lapida

Tomentella lateritia

Tomentella lilacinogrisea

Tomentella sp1.

Tomentella sp2.

Tomentella stuposa

Tomentella sublilacina

Tomentella terrestris

Tomentella umbrinospora

Tomentella viridescens

Tomentella viridula

Tomentellopsis bresadolana

Tomentellopsis cf submollis

Tomentellopsis echinospora

Tomentellopsis nigra

Tomentellopsis sp1.

Trametes hirsuta

Trametes ochracea

Trametes pubescens

Trechispora alnicola

Trechispora byssinella

Trechispora cohaerens

Trechispora farinacea

Trechispora hymenocystis

Trechispora kavinioides

Trechispora laevis

Trechispora microspora

Trechispora minima

Trechispora stellulata

Tremella foliacea

Tretomyces cf microsporus
Resupinate

Resupinate

Resupinate

Resupinate

Resupinate

Resupinate

Resupinate

Resupinate

Resupinate

Resupinate

Resupinate

Resupinate

Resupinate

Resupinate

Resupinate

Resupinate

Resupinate

Resupinate

Resupinate

Resupinate

Resupinate

Pileate

Pileate

Pileate

Resupinate

Resupinate

Resupinate

Resupinate

Resupinate

Resupinate

Resupinate

Resupinate

Resupinate

Resupinate

Ramarioid

Resupinate
331.3

1.00

Yes

$\begin{array}{llll}402.12 & 1.00 & \text { Yes } & 8\end{array}$

113.65

1.00

Yes

259.44

1.07

Yes

$304.17 \quad 1.26 \quad$ Yes

$572.56 \quad 1.00 \quad$ Yes

331.34

$1.00 \quad$ Yes

307.88

1.14 Yes

111.33

1.56 Yes

307.88

1.14 Yes

673.38

$1.00 \quad$ Yes

364.47

$1.10 \quad$ Yes

346.43

1.23 Yes

288.63

1.07 Yes

331.34

$1.00 \quad$ Yes

350.90

1.17 Yes

169.65

$1.00 \quad$ Yes

101.89

1.21

98.17

1.00

572.56

1.00

130.67

$1.00 \quad$ Yes

22.24

2.66

No

39.51

$2.56 \quad$ No

28.19

2.77

No

$1.28 \quad$ Yes

24.44

14.91

1.67 No

11.00

1.75

No

49.70

1.20

Yes

1.19 Yes

59.69

13.92

1.56 No

26.15

1.23 Yes

35.26

1.31 Yes

35.60

1.06 Yes

22.97

1.08 Yes

436.35

1.19 No

9.12

1.09

$$
\text { No }
$$


Trichaptum abietinum

Trichoderma

minutisporum/pachybasioides

Trichoderma pulvinatum

Trichoderma strictipile

Trichoderma viride

Tricholomopsis decora

Trichophaeopsis bicuspis

Trichosphaeria notabilis

Tubaria conspersa

Tubaria furfuracea

Tubulicrinis accedens

Tubulicrinis angustus

Tubulicrinis borealis

Tubulicrinis calothtrix

Tubulicrinis chaetophorus

Tubulicrinis glebulosus

Tubulicrinis medius

Tubulicrinis propinquus

Tubulicrinis sororius

Tubulicrinis strangulatus

Tubulicrinis subulatus

Tulasnella albida

Tulasnella allantospora

Tulasnella brinkmannii

Tulasnella cf conidiata

Tulasnella cystidiophora

Tulasnella eichleriana

Tulasnella fuscoviolacea

Tulasnella pallida

Tulasnella subglobospora

Tulasnella tomaculum

Tulasnella violea

Tylospora asterophora

Tylospora fibrillosa

Tympanis sp1.
Pileate

Stromatoid

34.64

48.35

2.24

No

1.32 Yes

Stromatoid

31.81

1.50

98.84

$1.10 \quad$ Yes

Stromatoid

60.75

$1.47 \quad$ Yes

Stromatoid

Agaricoid

Discomycetoid

$184.13 \quad 1.41 \quad$ No

Pyrenomycetoid

Agaricoid

Agaricoid

Resupinate

Resupinate

Resupinate

Resupinate

Resupinate

Resupinate

Resupinate

Resupinate

Resupinate

Resupinate

Resupinate

Resupinate

Resupinate

Resupinate

Resupinate

Resupinate

Resupinate

Resupinate

Resupinate

Resupinate

Resupinate

Resupinate

Resupinate

Resupinate

Discomycetoid $\begin{array}{lll}1527.07 & 1.38 \quad \text { No }\end{array}$

$\begin{array}{lll}547.52 & 2.54 \quad \text { No }\end{array}$

214.23

$1.43 \quad$ No

$\begin{array}{lll}178.59 & 1.57 \quad \text { No }\end{array}$

$\begin{array}{lll}30.76 & 1.53 \quad \text { No }\end{array}$

$26.94 \quad 5.00 \quad$ No

$\begin{array}{lll}18.85 & 3.00 \quad \text { No }\end{array}$

16.84

4.00

No

1.85 No

49.77

$4.00 \quad$ No

20.71

16.84

4.00

No

$4.24 \quad$ No

14.43

3.43

No

$1.00 \quad$ No

14.62

$4.00 \quad$ No

16.84

87.47

1.22

No

$\begin{array}{lll}49.00 & 3.00 \quad \text { No }\end{array}$

265.81

3.16

384.85

1.43

No

98.17

$1.00 \quad$ No

22.27

1.36

No

$\begin{array}{lll}170.24 & 2.82 \quad \text { No }\end{array}$

259.67

1.74

248.87

1.15 No

32.67

2.00

127.63

$1.30 \quad$ No

70.93

1.18 No

110.75

1.32

Yes

$4.75 \quad$ No

238.76
37

3

14

1

4

4

1

1

6

7

8

1

43

34

1

12

15

1

3

15

59

2

1

1

2

4

11

1

1

1

1

17

4

41

11

10

119 
Urceolella sp nov.

Vaginatispora cf fuckelii

Wallrothiella congregata

Vararia investiens

Veluticeps abietina

Xenasma pulverulentum

Xenasma rimicola

Xenasma tulasnelloideum

Xenasmatella borealis

Xenasmatella subflavidocrisea

Xenasmatella vaga

Xenolachne longicornis

Xeromphalina campanella

Xeromphalina picta

Xylodon asperus

Xylodon borealis

Xylodon brevisetus

Xylodon detriticus

Xylodon nespori

Xylodon radula

Xylodon rimosissimus

Xylodon sambuci

Total occurrence of species

\begin{tabular}{|c|c|c|c|c|c|c|c|c|}
\hline Discomycetoid & 61.14 & 2.61 & No & - & - & - & 1 & 1 \\
\hline Pyrenomycetoid & 182.21 & 3.63 & No & 4 & - & - & 10 & 14 \\
\hline Pyrenomycetoid & 10.93 & 1.22 & No & - & 1 & - & - & 1 \\
\hline Resupinate & 82.96 & 3.08 & No & 1 & - & - & - & 1 \\
\hline Pileate & 174.95 & 2.44 & No & - & 3 & - & - & 3 \\
\hline Resupinate & 282.74 & 1.67 & Yes & - & - & - & 1 & 1 \\
\hline Resupinate & 306.80 & 1.60 & Yes & - & - & - & 1 & 1 \\
\hline Resupinate & 87.47 & 1.22 & Yes & - & - & - & 2 & 2 \\
\hline Resupinate & 45.63 & 1.69 & Yes & - & - & 1 & - & 1 \\
\hline Resupinate & 15.90 & 1.78 & Yes & - & - & 1 & - & 1 \\
\hline Resupinate & 74.48 & 1.24 & Yes & 14 & 12 & 18 & 11 & 55 \\
\hline Discomycetoid & 87.11 & 3.23 & No & - & - & 1 & 1 & 2 \\
\hline Agaricoid & 67.35 & 2.00 & No & - & 1 & 1 & - & 2 \\
\hline Agaricoid & 119.28 & 1.67 & No & 1 & - & - & - & 1 \\
\hline Resupinate & 60.75 & 1.47 & No & 3 & 6 & 6 & 6 & 21 \\
\hline Resupinate & 55.22 & 1.33 & No & - & - & - & 1 & 1 \\
\hline Resupinate & 37.33 & 1.38 & No & 5 & 32 & 26 & 3 & 66 \\
\hline Resupinate & 74.48 & 1.24 & No & 2 & - & - & 7 & 9 \\
\hline Resupinate & 20.87 & 2.33 & No & - & - & 1 & - & 1 \\
\hline Resupinate & 74.66 & 2.77 & No & 2 & 1 & - & - & 3 \\
\hline Resupinate & 60.75 & 1.47 & No & - & 1 & - & 2 & 3 \\
\hline \multirow[t]{2}{*}{ Resupinate } & 57.98 & 1.40 & No & - & - & - & 3 & 3 \\
\hline & & & & 1566 & 1422 & 1222 & 1504 & 5714 \\
\hline
\end{tabular}

\section{Consulted literature for fungal traits:}

Baloch, E., Gilenstam, G., Wedin, M., 2009. Phylogeny ans classification of Cryptodiscus, with taxonimic synopsis of the Swedish species. Fungal Divers. 38, 51-68.

Bernicchia, A., Gorjon, S.P., 2010. Fungi Europaei n ${ }^{\circ}$ 12: Corticiaceae s.1., Fungi Europaei. Candusso Edizioni, Alassio.

Boehm, E., Mugambi, G.K., Miller, a N., Huhndorf, S.M., Marincowitz, S., Spatafora, J.W., Schoch, C.L., 2009. A molecular phylogenetic reappraisal of the Hysteriaceae, Mytilinidiaceae and Gloniaceae (Pleosporomycetidae, Dothideomycetes) with keys to world species. Stud. Mycol. 64, 49-83S3. https://doi.org/10.3114/sim.2009.64.03

Breitenbach, J., Kränzlin, F., 1984. Fungi of Switzerland: Ascomycetes, Vol. 1. Verlag Mykologia, Luzern. Dennis, R.W.G., 1960. British cup fungi and their allies. The Ray Society, London.

Ellis, M., Ellis, J.P., 1997. Microfungi on land plants: An identification handbook. The Richmond Publishing Co. Ltd., Slough.

Eriksson, J., Hjortstam, K., Ryvarden, L., 1984. The Corticiaceae of North Europe, Vol. 7. Fungiflora, Oslo. Eriksson, J., Hjortstam, K., Ryvarden, L., 1981. The Corticiaceae of North Europe, Vol. 6. Fungiflora, Oslo. 
Eriksson, J., Hjortstam, K., Ryvarden, L., 1978. The Corticiaceae of North Europe, Vol 5. Fungiflora, Oslo. Eriksson, J., Ryvarden, L., 1976. The Corticiaceae of North Europe, Vol 4. Fungiflora, Oslo.

Eriksson, J., Ryvarden, L., 1975. The Corticiaceae of North Europe, Vol 3. Fungiflora, Oslo.

Eriksson, J., Ryvarden, L., 1973. The Corticiaceae of North Europe, Vol. 2. Fungiflora, Oslo.

Hansen, L., Knudsen, H., 2000. Nordic Macromycetes: Ascomycetes, Vol. 1. Nordsvamp, Copenhagen.

Hansen, L., Knudsen, H., 1997. Nordic Macromycetes: Heterobasidioid, Aphyllophoroid and Gastromycetoid Basidiomycetes, Vol.3. Nordsvamp, Copenhagen.

Hjortstam, K., Larsson, K.-H., Ryvarden, L., 1988. The Corticiaceae of North Europe, Vol. 8. Fungiflora, Oslo.

Huhtinen, S., 1989. A monograph of Hyaloscypha and allied genera. Karstenia 29, 45-252.

International Mycological Association, 2017. Mycobank [WWW Document]. http://www.mycobank.org/.

Knudsen, H., Vesterholt, J., 2008. Funga Nordica. Nordsvamp, Copenhagen.

Miller, A.N., Huhndorf, S.M., Fournier, J., 2014. Phylogenetic relationships of five uncommon species of Lasiosphaeria and three new species in the Helminthosphaeriaceae (Sordariomycetes). Mycologia 106, 505-524. https://doi.org/10.3852/13-223

Munk, A., 1957. Danish pyrenomycetes -A preliminary flora. Dansk Bot. Ark. 17, 1-491.

Niemelä, T., 2005. Käävät, puiden sienet. Norrlinia 13, 1-320.

Raitviir, A., 2004. Revised synopsis of the Hyaloscyphaceae. Scr. Mycol. 20, 1-132.

Raitviir, A., Huhtinen, S., 2002. A few out of many -interesting inoperculate, lignicolous discomycetes from Norway. Folia Cryptogam. Est. 39, 13-26.

Re, M., 2006. Molecular systematics of Ceratostomella sensu lato and morphologically similar fungi 98, 6893.

Royal Botanic Gardens Kew, Landcare Research-NZ, Chinese Academy of Science, 2017. Index fungorum [WWW Document]. Www.indexfungorum.org.

Sherwood, M.A., 1977. The Ostropalean fungi. Mycotaxon 5, 1-277. 


\section{Morphological traits predict host-tree specialization in wood-inhabiting fungal communities}

Purhonen Jenna, Ovaskainen Otso, Halme Panu, Komonen Atte, Huhtinen Seppo, Kotiranta Heikki, Læssøe Thomas, \& Abrego Nerea

Supplementary Material 3

TABLE 1 Kruskal-Wallis ANOVA chi-square test coefficients and P-values (df for all groups is 3 ) as well as Pvalues for Nemenyi pairwice comparisons of average species richness per log among the tree species for the total species richness and also separately for the fruitbody groups.

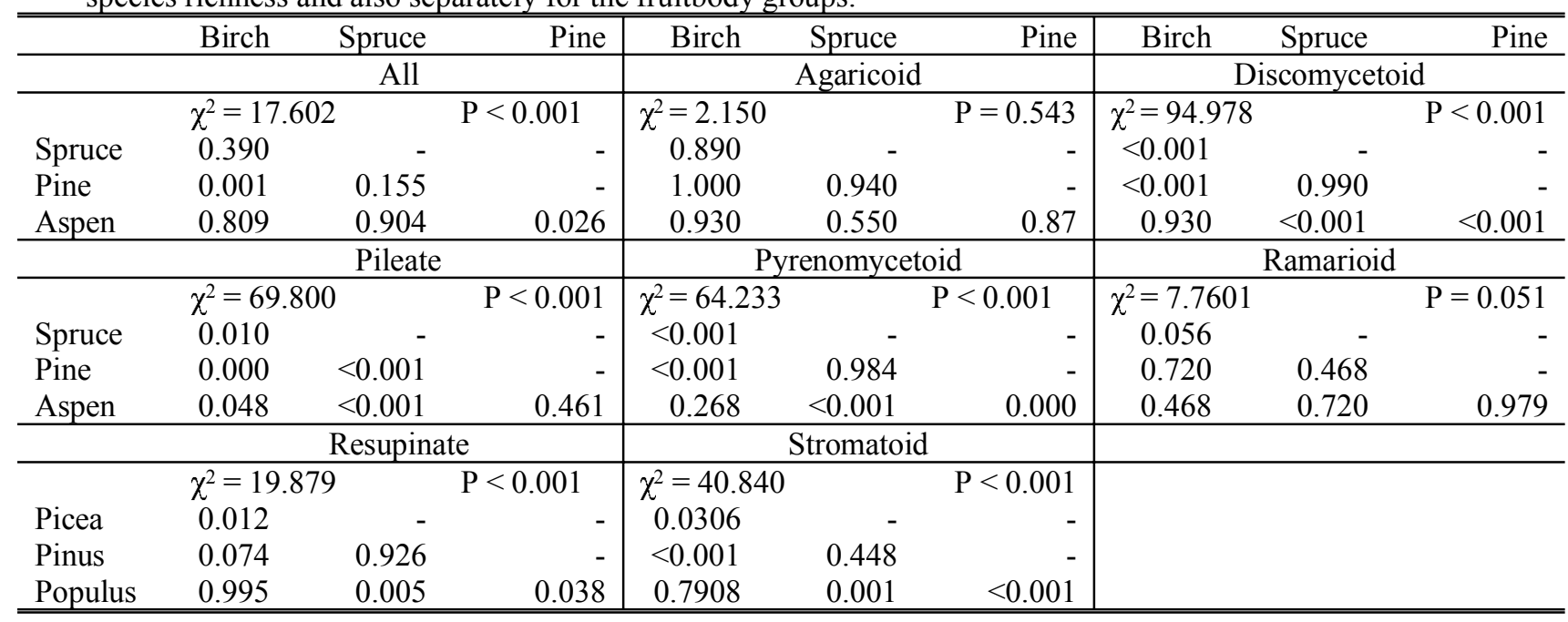

